\title{
TAXONOMIC STUDIES ON THE SUPERFAMILY PTEROPHOROIDEA (LEPIDOPTERA) FROM NORTHWESTERN INDIA
}

\author{
H.S. Rose and H.S. Pooni \\ Department of Zoology, Punjabi University, Patiala-147 002, Punjab, India \\ E-mail: profhsrose@yahoo.com
}

\begin{abstract}
Eighteen species belonging to 14 genera viz., Deuterocopus Zeller (Deuterocopinae), Oxyptilus Zeller, Sphenarches Meyrick, Stenoptilia Hübner, Stenoptilodes Zimmerman, Lantanophaga Zimmerman, Amblyptilia Hübner, Gypsochares Meyrick, Exelastis Meyrick, Tomotilus Yano, Procapperia Adamczewski, Megalorrhipida Amsel, Prichotilus gen. nov. and Stenodacma Amsel (Pterophorinae) of the respective subfamily of the family Pterophoridae (Pterophoroidea) have been collected from northwestern India and dealt with taxonomically. Key to the presently examined 13 genera of the subfamily Pterophorinae has been prepared on the basis of wing venation and male and female genitalic characters. Further, keys to the species of the genera such as Exelastis Meyrick, Megalorrhipida Amsel and Stenodacma Amsel represented by more than one species have also been furnished. The genus Tomotilus Yano is being reported for the first time from India. The distribution of the species Deuterocopus planeta Meyrick, Stenoptilia petraea Meyrick, Stenoptilodes taprobanes (Felder and Rogenhöfer), Amblyptilia forcipeta (Zeller), Exelastis phlyctaenias Meyrick, Procapperia pelecyntes (Meyrick) and Trichoptilus bidens Meyrick stands updated through an addition of more localities from northwestern India. Three new species, one of genus Lantanophaga and two of genus Megalorrhipida have been reported from the area, under reference. Besides giving an illustrated account of the new species, the genitalic account of already known species have been added to improve the descriptive account of these biological species.
\end{abstract}

KEYWORDS

Taxonomy, Lepidoptera, Pterophoridae, Pterophorinae, Deuterocpinae, plume moths, northwestern India, genitalia.

AbBreviations

AED: Aedeagus, AN.L.: Anellus lobes, ANT. APO: Anterior Apophyses, AT: Antrum, CL: Cucullus, FRH: Forest Rest House, FRI: Forest Research Institute, JX: Juxta, KV: Krishi Vishawvidyalya, NHM: Natural History Museum, PU: Punjab University, PUP: Punjabi University, Patiala, SA: Saccus, SOC: Soccii, T.A.: Tuba analis, TEG: Tegumen, UHF: University of Horticulture and Forestry, UN: Uncus.

The superfamily Pterophoroidea is a unique group of slenderlybuilt moths with long legs and narrow and fissured/clefted wings. The forewing may have one, sometimes two and rarely three clefts, whereas, the hindwing is always clefted twice. The moths referred to this superfamily are commonly called the 'plume-moths'. Except for Meyrick $(1905,1906,1907,1911)$ and Fletcher $(1909,1914,1921,1925,1926,1931,1940)$, no concrete attempt has been made by any other worker to collect and study these moths from India. The fact remains that due to their being smaller in size and difficult to handle taxonomically, this group of moths pose serious problems in collection and identification. Accordingly, in this paper an effort has been made to fill the gaps in our knowledge on this group of moths from northwestern India.

\section{Methodology}

In view of the nocturnal behavior of pterophorid moths, their collection was done with the help of a portable light trap fitted with $125 \mathrm{w}$ mercury vapour lamp to attract the moths. The traps were installed near ground level amongst bushes as the moths are generally weak fliers. In addition to this, a mercury vapour lamp was also hung along a white cloth sheet secured to a wall or directly over a plain white wall. Specimens were then collected individually in small glass tubes. Each collected specimen was spread and pinned through the mid of mesothorax. The spread specimens were preserved in the insect storage boxes and fumigated with naphthalene balls. Specimen data such as date of collection, name of the locality, altitude and name of the collector etc. were written down. To prepare permanent slides of the wings, the method discussed by Common (1970) and advocated by Zimmerman (1978) has been followed. To study the external male and female genitalia, the method suggested by Robinson (1976) has been followed with slight modification. All specimens are deposited in the Lepidoptera Laboratory, Department of Zoology, Punjabi University, Patiala. Collection numbers will be assigned when part of the collection will be submitted to ZSI as per the understanding with the Ministry of Environment and Forests, Government of India. All the specimens were collected by the authors.

\section{Superfamily: Pterophoroidea}

Family: Pterophoridae

Pterophoridae Latreille, [1802], An X, Hist. nat. gén. Particuliére Crustacés Insectes 3: 418 (as Pterophorii).

Type-Genus: Pterophorous Schäffer, 1766, Elementa Entomologica: pl. 104, figs. 2,3.

Diagnosis: Head smooth, chaetosemata and ocelli absent, proboscis unscaled, maxillary palpus vestigial, labial palpus slender; forewing clefted once, twice or rarely thrice, veins $M_{1}$ and $M_{2}$ reduced or absent; hindwing always clefted twice, $M_{1}$ and $\mathrm{M}_{2}$ reduced or absent; legs long and slender, with long tibial spurs; female genitalia with anterior apophysis usually absent.

\section{Subfamily: Deuterocopinae}

Deuterocopinae Gielis, 1993, Zool. Verh. Leiden, 290: 66. Type-genus: Deuterocopus Zeller, 1852, Linn. ent., 6: 402. Diagnosis: Head smooth, chaetosemata and ocelli absent, 
proboscis unscaled, maxillary palpus vestigial, labial palpus slender; forewing clefted twice or thrice; veins $M_{1}$ and $M_{2}$ reduced or absent; hindwing always clefted twice, $M_{1}$ and $M_{2}^{2}$ reduced or absent; legs long, slender, tibial spurs relatively longer, usually with scale brushes around base of spurs; female genitalia with anterior apophysis usually wanting.

\section{Deuterocopus Zeller}

Deuterocopus Zeller, 1852, Linn. Ent., 6: 402.

Deuteroscopus (sic) Hofmann, 1898, Dt. Ent. Z. Iris, 11: 329.

Type-species: Deuterocopus tengstroemi Zeller, 1852, Linn. Ent., 6: 402, by monotypy.

\section{Deuterocopus planeta Meyrick}

Deuterocopus planeta Meyrick, 1908. Trans. ent. Soc. Lond., 1908: 473-474.

Material examined: 1 male, 4.iii.1998, 12 males, 4-20.viii.1998, 6 males, 12-25.ix.1998, 20 males, 1 female, 1-25.viii.1999, 3 males, 1-20.ix.1999, 1 male, 5.x.1999, PUP, Patiala, Punjab, 250m; 1 male, 2.vi.1998, one male, FRI, Dehradun, Uttaranchal, 700m.

Distribution: India (Coorg, Khasi Hills), Sri Lanka, Burma, Thailand, Timor, Kei Island, (Robinson et al., 1994).

\section{Diagnostic features}

Male genitalia (Figs. 1-4): Uncus small, slender, bearing backwardly directed setae; tuba analis well developed; tegumen bilobate, lobes well developed; valvae symmetrical, costa straight, sacculus well developed, long, broad, with a spannershaped bilobed structure dorso-distally, cucullus broad, bilobate, delimited by a neck, a long and slender process arising from neck dorsally, dorsal lobe of cucullus pointed, ventral lobe rounded, somewhat semi-oval in shape, terminally with a row of sparse and fine setae; aedeagus long, strongly sinuate, medially somewhat flattened, tip strongly curved, pointed, coecum absent; caulis small, slender.

Female genitalia (Fig. 5): Papillae anales thin, slender; anterior apophyses absent; posterior apophyses moderately long; ostium bursae centrally placed; antrum slightly sclerotized, ductus bursae narrow, slender; corpus bursae moderate in size, signum absent.

Alar expanse: Male and female 9-11 mm.

Larval host plant: Larva on flowers of Leea sambucina (Fletcher, 1921).

Remarks: On the basis of the forewing, which may be clefted twice or thrice, Gielis (1993) proposed a new subfamily Deuterocopinae with Deuterocopus Zeller as its type-genus. Out of all the four genera i.e., Deuterocopus Zeller, Heptaloba Walsingham, Hexadactyla Fletcher and Leptodeuterocopus Fletcher, the former with forewing clefted trifid contains seven species, namely, D. alopecodes Meyrick, D. atropex Fletcher, $D$. dorites Meyrick, D. fevens Meyrick, D. planeta Meyrick, D. ritsemae Walsingham and D. socotranus Rebel, which occur in
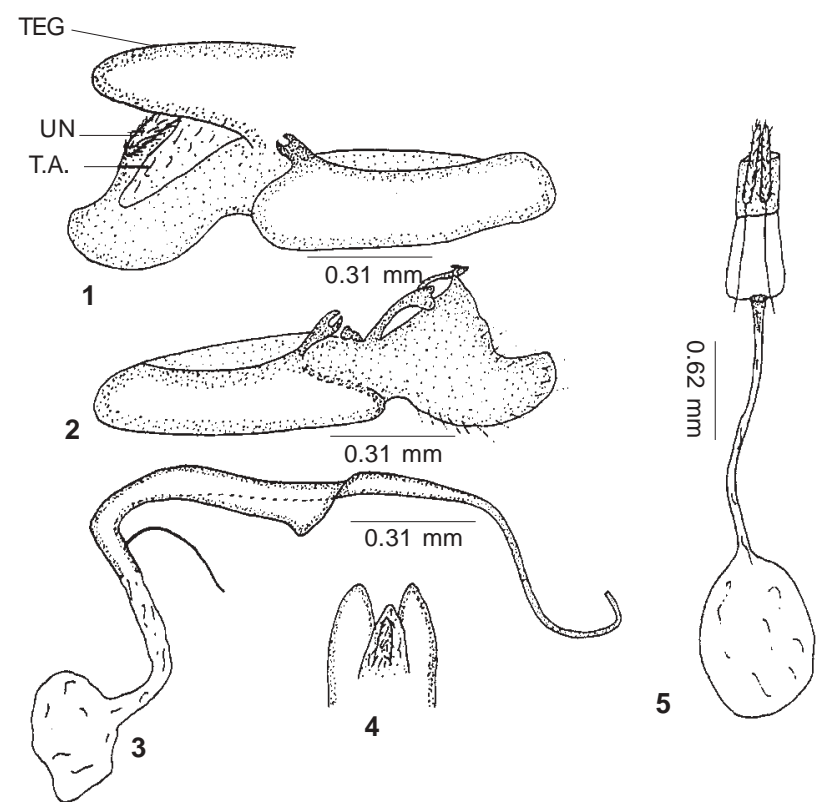

Figures 1-5. Dueterocopus planeta Meyrick 1 - Male genitalia (lateral view); 2 - Right valva; 3 - Aedeagus; 4 - Uncus; 5 - Female genitalia (ventral view)

India. The presently dealt with species i.e., Deuterocopus planeta Meyrick is one of the most common species available in India (Fletcher, 1931; Robinson et al., 1994). Though the specimens have been collected from only two aforesaid localities yet there is some difference in colouration from light fulvous to dark fulvous. In order to judge the conspecificity of such individuals, a series of fourteen dissections have been made and their conspecificity confirmed.

\section{Subfamily: Pterophorinae}

Pterophorinae Zeller, 1841, Isis von Oken, 10: 755.

Type-genus: Pterophorous Schäffer, 1766, Elementa Entomologica: pl. 104, figs. 2,3.

Diagnosis: Head smooth, chaetosemata and ocelli absent, proboscis unscaled, maxillary palpus vestigial, labial palpus slender; forewing always clefted only once; veins $M_{1}$ and $M_{2}$ reduced or absent; hindwing always clefted twice, $M_{1}$ and $\mathbf{M}_{2}$ reduced or absent; legs long and slender, with tibial spurs long, legs usually with scale brushes around base of spurs; female genitalia usually with anterior apophysis absent.

\section{Oxyptilus Zeller}

Oxyptilus Zeller, 1841, Isis Oken, Leipzig, 1841: 765.

Type-species: Oxyptilus pilosellae Zeller, 1841, ibidem, 1841: 765, by subsequent designation by Tutt, 1905, Entomologist's Rec. J. Var. 17: 35.

\section{Oxyptilus causodes Meyrick}

Oxyptilus causodes Meyrick, 1905, J. Bombay Nat. Hist. Soc., 16: 582.

Material examined: 1 male, 24.ix.1973, Solan, Himachal Pradesh, $1400 \mathrm{~m}$. 

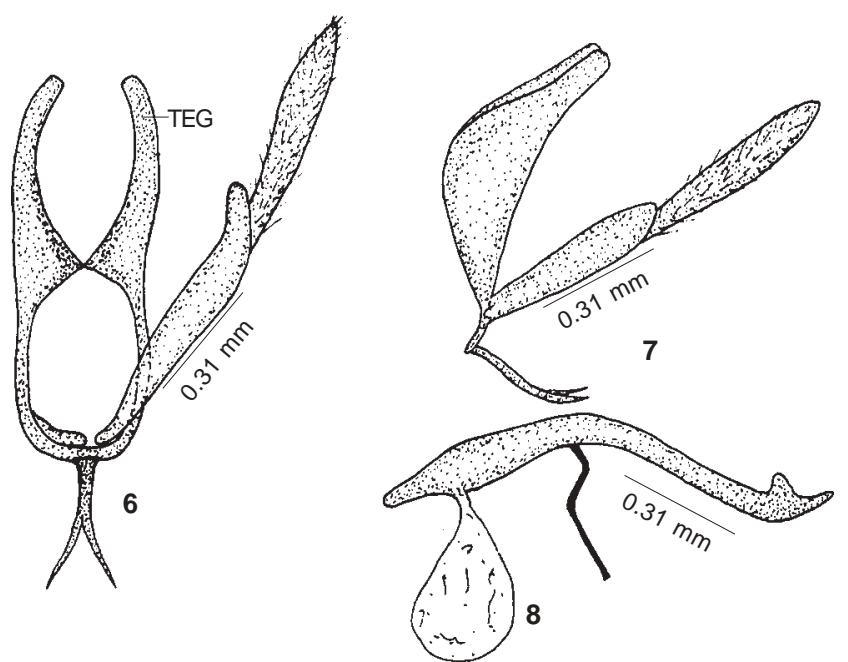

Figures 6-8. Oxyptilus causodes Meyrick. 6 - Male genitalia (ventral view); 7 - Male genitalia (lateral view); 8 - Aedeagus

Distribution: India (Bengal, southern India, Dehradun), Sri Lanka (Fletcher, 1931)

\section{Diagnostic features}

Male genitalia (Figs. 6-8): Uncus absent; tegumen well developed, top bilobate, lobes well developed; vinculum weak, broad, U-shaped; saccus long, slender, forked beyond middle, with pointed apices; valvae symmetrical, long, cucullus separated as a semi-oval lobe, latter pointed apically, inner surface with very fine setae sparsely arranged, sacculus ending as an oval outgrowth at the base of cucullus; aedeagus long, strong, gradually curved in middle, coecum well developed; ductus ejaculatorius entering ventrally, a well sclerotized small protuberance dorsally before apex, apex slightly curved dorsally, tip pointed.

Female genitalia: Not examined.

Alar expanse: Male $15 \mathrm{~mm}$.

Larval host plant: Larva in fruits of Dillenia retusa and $D$. indica (Fletcher, 1931).

Remarks: Apart from the species, under reference, the genus is represented by six species -- $O$. chordites Meyrick, $O$. lactucae Fletcher, O. epidectis Meyrick, O. paedator Meyrick, $O$. regalis Fletcher and $O$. regulus Meyrick from India. Worldwide, excluding Indian species, the genus includes 23 species mainly from the Palaearctic and a few from the Nearctic and African regions (Gielis, 1993).

\section{Sphenarches Meyrick}

Sphenarches Meyrick, 1886, Trans. Ent. Soc. Lond., 1886: 8. Sphenarctes (sic) Carus, 1887, Zool. Anz., 10: 113.

Type-species: Sphenarches synophrys Meyrick, 1886, (= Oxyptilus anisodactylus Walker, 1864) ibidem, 1886: 17, by monotypy.
Sphenarches anisodactylus Walker

Oxyptilus anisodactylus Walker, 1864, List Specimens lepid. Insects Colln. Br. Mus., 30: 934.

Material examined: Uttaranchal: Dist. Dehradun; FRI, 700m, 1 male, 2 females, 16-18.v.1973, 2 males, 20.viii, 1973, two males, 1 female, 3.ix.1973, FRI, Dehradun, Uttaranchal, 750m; 2 males, 2 females, Chambaghat, Solan district, Himachal Pradesh, 1200m; 1 male, 17.viii.1999, PUP, Patiala, Punjab, 250m; 1 female, 20.ix.1973, PU, Chandigarh, 300m.

Distribution: Cosmopolitan (Fletcher, 1931; Gielis, 1993).

\section{Diagnostic features}

Male genitalia (Figs. 9-11): Uncus small, slender, setosed, clavate; tuba analis well developed; tegumen narrow, high, apically pointed, with a brush of long fine hair; vinculum weak, with a plate-like saccus; valvae symmetrical, long, spoonshaped, basally narrow, costa convex, sacculus not differentiable, cucullus well developed, arched, twisted, broadest in middle, narrowing apically, rounded distally, with a row of inwardly directed dense hair; aedeagus long, slender, gradually curved, somewhat sickle-shaped, tip straight, pointed; caulis small, broad.

Female genitalia (Fig. 12): Papillae anales flat, broad; anterior apophyses absent, posterior apophyses very long; ostium bursae centrally placed; antrum tube-like; ductus bursae long, slender; corpus bursae moderate in size, globular in shape, signum absent; ductus seminalis opening at the junction of ductus bursae and corpus bursae.

\section{Alar expanse: Male and female 14-16mm.}

Larval host plants: Dolichos lablab, Cucurbita (Fletcher, 1909).

Remarks: The individuals collected from the aforesaid localities were dissected (one from each locality) and found to be conspecific and the species was identified as Sphenarches anisodactylus Walker (Gielis, 1993). The genus Sphenarches was proposed on the basis of a new species i.e., S. synophrys by Meyrick (1886). While considering $S$. caffer Zeller as a typespecies of this genus, Fletcher (1909) synonymized both these species i.e., S. synophrys Meyrick and S. anisodactylus Walker under the former name.

Relevant literature reveals that there exists some confusion regarding the wing venation in the genus Sphenarches Meyrick. In the original diagnosis, Meyrick (1886) recorded that the veins $2\left(\mathrm{CuA}_{2}\right)$ and $4\left(\mathrm{M}_{1}\right)$ are stalked, $3\left(\mathrm{CuA}_{1}\right)$ absent, $8\left(\mathrm{R}_{4}\right)$ and 9 $\left(\mathrm{R}_{3}\right)$ stalked and $10\left(\mathrm{R}_{2}\right)$ and $11\left(\mathrm{R}_{1}\right)$ stalked in the forewing. Adamczewski (1951) redescribed the genus without making any comment on the wing venation on which the genus was founded. Gielis (1993) has redescribed the genus and discussed the wing venation after the observations made by Yano (1963), wherein it is mentioned that the vein $R_{1}$ is stalked with $R_{2}$, vein $C u A_{1}$ present and there is no mention about the position of the veins $\mathrm{R}_{3}$ and $\mathrm{R}_{4}$. Mathews (1989) has furnished a figure of the venation 


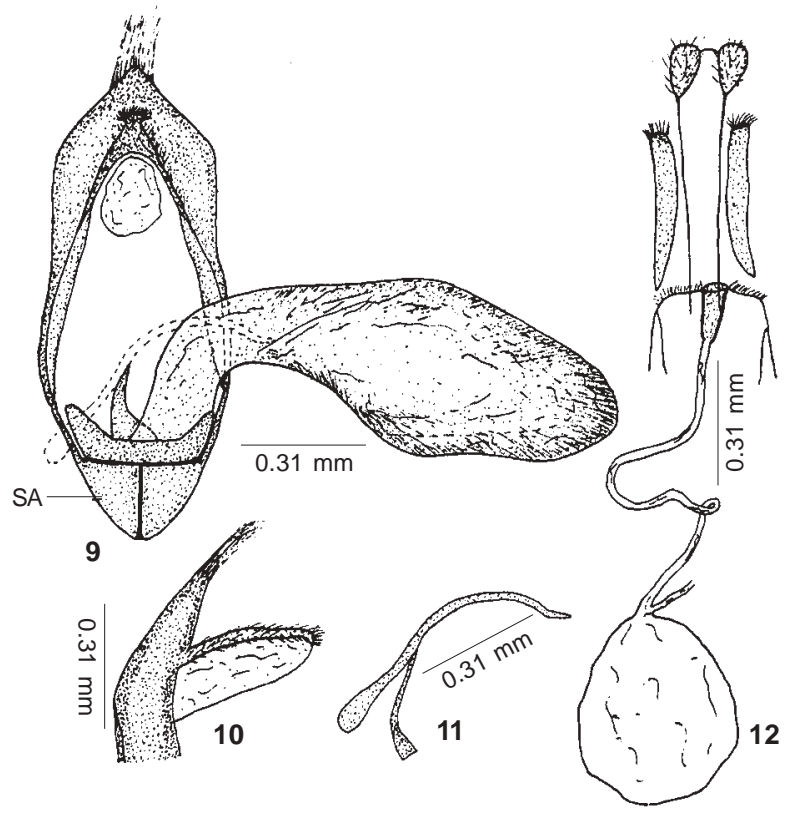

Figures 9-12. Sphenarches anisodactylus Walker 9 - Male genitalia (ventral view); 10 - Uncus (lateral view); 11 - Aedeagus; 12 - Female genitallia (ventral view)

of the forewing where the vein $R_{1}$ is shown stalked with $R_{2}$ and vein $R_{3}$ with $R_{4}$. Also, the vein $\mathrm{CuA}_{1}$ is shown to be present. The present examination of the wing venation goes in accordance to the diagram given by Gielis (1993), after Mathews (1989).

The species is distributed throughout the tropics except in the Hawaiian Islands and is also present in some Pacific Islands (Adamczewski, 1951). In India, it has earlier been reported from Andaman Island, Palni Hills, Coorg, Surat, Anamalais, Pusa, Allahabad, Shillong and Bhim Tal (Fletcher, 1931). The species is moderately common in northwestern India.

\section{Stenoptilia Hübner}

Stenoptilia Hübner, [1825] 1816, Verz. Bekannter Schmett.: 430. Mimaeseoptilus Wallengren, 1862, K. Svenska. Vetensk Akad. Handl. (N.F.) 3 (7): 17. Type-species: Alucita mictodactyla [Denis and Schiffermüller], 1775, Ankündung Syst. Werkes Schmett. Wienergegend: 320.

Mimeseoptilus Zeller, 1867, Stettin. Ent. Ztg, 28: 332. (unjustified emend.)

Mimaeseoptilus (sic) Snellen, 1884, Tijdschr. Ent. 27: 184.

Mimaesoptilus Barret, (sic), 1904, Lepid. Br. Isl. 9: 373.

Doxosteres Meyrick, 1886, Trans. Ent. Soc. Lond., 1886: 10. Type-species: Pterophorus canalis Walker, 1864, List Specimens lepid. Insects Colln. Br. Mus., 30: 944, by monotypy. Adkinia Tutt, 1905, Entomologist's Rec. J. Var. 17: 37. Typespecies: Phalaena bipunctidactyla Scopoli, 1763, Ent. Carrioclica: 257 , by original designation.

Type-species: Phalaena pterodactyla Linnaeus, 1761, Fauna Suecia (Edn 2); 371, by subsequent designation by Tutt, 1905, Entomologist's Rec. J. Var. 17: 35.

\section{Stenoptilia petraea Meyrick}

Stenoptilia petraea Meyrick, 1908, Trans. Ent. Soc. Lond., 1908: 504.

Material examined: 3 males, 1 female, 27.x.2001, Dunera, Gurdaspur district, Punjab, 700m; 2 males, 1 female, 23.x.2001, FRH, Dhar, Punjab, 700m; 3 males, 1 female, 26.x.2001, Punjab FRH, Ghatasani, Dalhousie district, Himachal Pradesh, 1100m. , 1 male, 27.ix.1973, Solan, Himachal Pradesh; 2 males, 12.iv.1991, Renuka Lake, Sirmour district, Himachal Pradesh, 740m.

Distribution: India (Palni Hills, Nilgiri Hills), Sri Lanka (Gielis, 1993).

\section{Diagnostic features}

Male genitalia (Figs. 13 \&14): Uncus small, pointed, somewhat conical; tuba analis membranous, but traceable; tegumen moderately broad, high, bilobate, lobes rounded, with dorsally directed long hair apically; vinculum v-shaped, saccus absent; valvae symmetrical, costa slightly arched, terminally with a patch of dense hair, sacculus long and broad, ventro-distally with a bunch of very long hair, cucullus narrow, bilobate, somewhat bird-head like, upper lobe long, curved, hairy, pointed to form a long beak, lower lobes broad, rounded; aedeagus long, curved, basally strongly bent, coecum well developed, ductus ejaculatorius present opposite caulis, tip pointed.

Female genitalia (Fig. 15): Papillae anales very small, somewhat rounded; anterior apophyses absent, posterior apophyses very long; ostium bursae centrally placed; seventh sternite slightly sclerotized, hairy around ostium; antrum long, tub-like, reaching middle, narrow towards distal margin, cestum developed in distal half; corpus bursae large, globular, with two large horn-like signae.
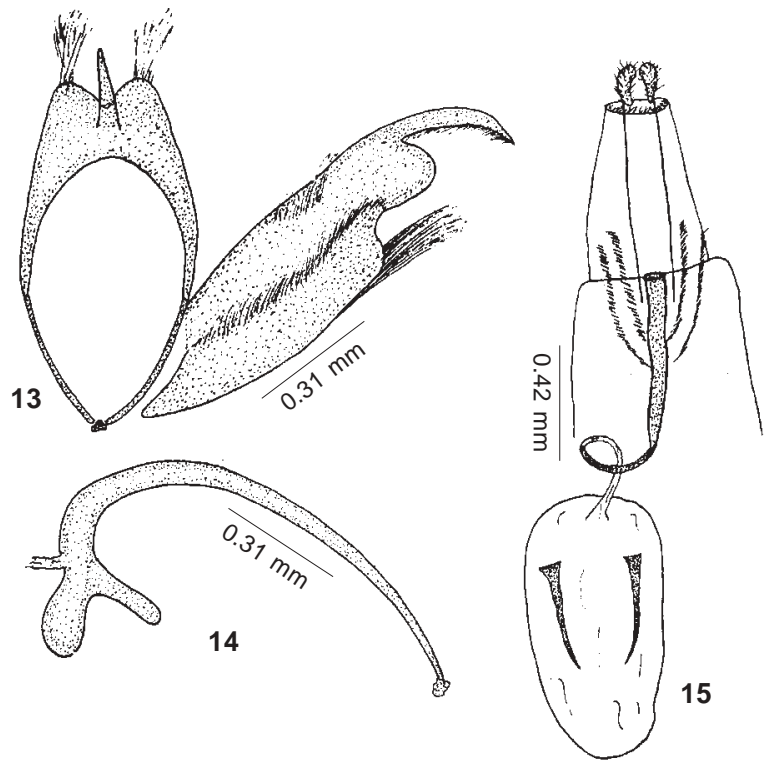

Figures 13-15. Stenoptilia petraea Meyrick 13 - Male genitalia (ventral view); 14 - Aedeagus; 15 - Female genitallia (ventral view) 
Alar expanse: Male and female 19-20mm.

\section{Larval host plant: Unknown}

Remarks: Fletcher $(1909,1931)$ reported the species zophodactyla Duponchel and patraea Meyrick under the genus Stenoptilia Hübner from India. The male genitalia of the present species S. patraea Meyrick is clearly congeneric with the species Stenoptilia zophodactyla Duponchel as evident from the diagram of male and female genitalia given by Gielis (1993). However, both the species can be distinguished from each other on the basis of structure of the cucullus and size and shape of the aedeagus. As mentioned above, this species has earlier been reported from Palni and Nilgiri Hills in India and the present distributional area is new to the species.

\section{Stenoptilodes Zimmerman}

Stenoptilodes Zimmerman, 1958, Insects Hawaii, 8: 407. Type-species: Platyptilus littoralis Butler, 1882, Trans. Ent. Soc. Lond., 1882: 44, by original designation.

\section{Stenoptilodes taprobanes Felder and Rogenhöfer} Amblyptilia taprobanes Felder and Rogenhöfer, 1875, Reise Novara, Lepid. Het.: pl. 140, fig. 54.

Material examined: 1 male, 27.ix.1973, Solan, Himachal Pradesh.

Distribution: India (Coorg, Pusa), Sri Lanka, Burma, Australia, USA, Brazil, Cyprus, South Africa, Mauritius, Hawaiian Islands (Fletcher, 1931).

\section{Diagnostic features}

Male genitalia (Figs. 16-18): Uncus long, slender, apically pointed, broader at base; tuba analis well developed, conical, slightly sclerotized, separable as scaphium and sub-scaphium; tegumen broad, high, top bilobate, lobes rounded; vinculum reduced; saccus absent; valvae symmetrical, long, costa long, straight; sacculus long, broad, dorso-basally with a row of dense

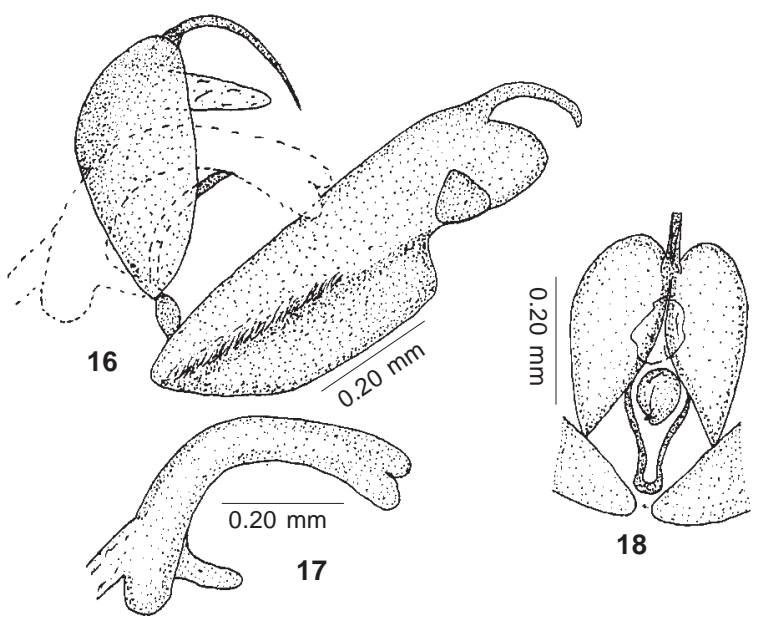

Figures 16-18. Stenoptilia taprobanes Felder \& Rogenhofer 16 - Male genitalia (lateral view); 17 - Aedeagus; 18 - Tegumen (ventral view) small hair, cucullus moderate, bilobed, bird-head like, dorsal lobe long, curved, beak-like, lower lobe small somewhat rounded, ventrally delimited by a neck, basally with a triangular plate; aedeagus broad, stout, gradually curved, somewhat expanded posteriorly, bipartite, coecum moderate, ductus ejaculatorius opposite to caulis, anellus lobes well developed, support aedeagus laterally.

Female genitalia: Not examined.

Alar expanse: Male $13 \mathrm{~mm}$.

Larval host plants: Celsia coromacdeliana, Limnophila heterophylla, Pentstemon, Veronica anagallis (Fletcher, 1931).

Remarks: While reviewing the diagnosis of genera Stenoptilia Hübner and Stenoptilodes Zimmerman, Gielis (1993) reported that top of the valva (cucullus) is bird head-like and the saccus is absent in the male genitalia of both these genera. However, these have been differentiated on the basis of the uncus which is reduced in the former and long, slender and half to one times as long as tegumen in the latter. Following this characterization, the present lone specimen has been found to belong to the genus Stenoptilodes Zimmerman and identified as Platyptilia taprobanes from the reference collections at FRI, Dehradun (Roonwal et al., 1964). This is the only species of this genus to be known from India (Gielis, 1993) and seems to be quite rare as per present survey.

\section{Lantanophaga Zimmerman}

Lantanophaga Zimmerman, 1958, Insects Hawaii, 8: 400.

Type-species: Oxyptilus pussillidactylus Walker, 1864, List Specimens lepid. Insects Colln. Br. Mus., 30: 933, by original designation.

\section{Lantanophaga anellatus sp. nov.}

\section{Material examined:}

Holotype: Male, 23.x.2001, FRH, Dhar, Gurdaspur district, Punjab, 700m.

Paratypes: 25 males, 16 females, 23.x.2001, FRH, Dhar, Gurdaspur district, Punjab, 700m.; 8 males, 6 females, 10.xi.2001, Dunera, 700m; 21 males, 16 females, 26.x.2001, Punjab FRH, Ghatasani, Dalhousie district, Himachal Pradesh, 1100m.

Distribution: India: Punjab, Himachal Pradesh.

Etymology: The species is so named due to species specific modified anellus lobes around the aedeagus in the male genitalia.

\section{Diagnostic features}

Male and Female: Vertex and frons dark greyish-fuscous; antenna filiform, black, with pale spots; labial palpus moderate in size, two times diameter of eye, almost porrect, greyish-black, with white and black patches, third segment small (Fig. 19); thorax covered with greyish-fuscous scales mixed with white scales; forewing clefted bifid, cleft deep upto distal one-third, 
costa strongly arched in the middle of cleft, apex acute, termen oblique, concave, tornus well defined, apex of second lobe acute, termen oblique, sinuate, tornus defined, covered with a mixture of ochreous and fuscous scales, a dark fuscous spot at the base of cleft, a fine white line running parallel and oblique to termen, continuous in both lobes, fringes whitish-grey, tornal cilia black, cilia on termen with dark base; hindwing clefted trifid, first lobe widened distally, apex rounded sub-acute, second and third lobes with acute apices; legs pale ochreous with fuscous spots; abdomen greyish-fuscous, dorsally with mixed white scales.

Wing venation (Figs. 20-21): Forewing with Sc ending almost in middle of costal margin, all radial veins present, $R_{3}$ and $R_{4}$ stalked, stalk originating from upper angle of cell, $\mathrm{R}_{4}$ ending at apex of first lobe, $\mathrm{R}_{5}$ ending at tornus of first lobe, $\mathrm{M}_{1}, \mathrm{M}_{2}$ vestigial, $\mathrm{M}_{3}$ and $\mathrm{Cu} \mathrm{A}_{1}$ connate at lower angle of cell, $\mathrm{M}_{3}$ ending at apex of second lobe, $\mathrm{Cu}_{1}$ ending at termen of second lobe, $\mathrm{CuA}_{2}$ arising in the posterior one-fourth of cell, CuP absent, two anal veins $(1 \mathrm{~A}+2 \mathrm{~A}$ and $3 \mathrm{~A})$ present; hindwing with $\mathrm{Sc}+\mathrm{R}_{1}$ ending near apex at costal margin, Rs ending at termen of first lobe below apex, discocellulars incomplete, $\mathrm{M}_{1}$ and $\mathrm{M}_{2}$ absent, $\mathrm{M}_{3}$ ending at apex of second lobe, $\mathrm{CuA}_{1}$ arising at the point of lower angle of cell, $\mathrm{CuA}_{2}$ arising in the middle of cell, $\mathrm{CuP}$ absent, third lobe with only one anal vein $(1 \mathrm{~A}+2 \mathrm{~A})$ present, $3 \mathrm{~A}$ absent.

Male genitalia (Figs. 22-24): Uncus long, slender, curved, pointed apically, broader at base; tegumen broad, high, top rounded, with a brush of long hair; vinculum weak; saccus long, slender, curved, forked apically; valva long, broad, costa straight, slightly arched, sacculus broad, dorsally with a bunch of long dense hair, terminally ending in a small pointed dent, cucullus long, broad, somewhat bird head-like, dorsal margin straight, somewhat convex, terminally produced into a pointed beaklike structure, latter with 7-8 very fine setae, ventral margin delimited by a small construction with a row of fine dense hair; aedeagus long, slender, strongly sinuate, globular basally, gradually narrowing towards apex, slender apically, pointed, thread-like, coecum well developed, ductus ejaculatorius opposite to caulis, ventrally supported by juxta and laterally by anellus lobes, lobes dentate dorsally.

Female genitalia (Fig. 25): Papillae anales small, pointed; anterior apophyses absent, posterior apophyses very long; ostium bursae centrally placed, seventh sternite moderately sclerotized to form lamella antivaginalis, medio-laterally produced into small anterior apophyses, lamella postvaginalis bilobed, antrum long, tube like, curved; ductus bursae long, slender, slightly sclerotized; corpus bursae moderate in size, globular in shape, with two small s-shaped signae; ductus seminalis enters in the proximal part of ductus bursae near corpus bursae.

Alar expanse: Male and female 12-13mm.

\section{Larval host plant: Unknown}

Remarks: According to Gielis (1993), the genus Lantanophaga Zimmerman besides its type-species i.e., Oxyptilus
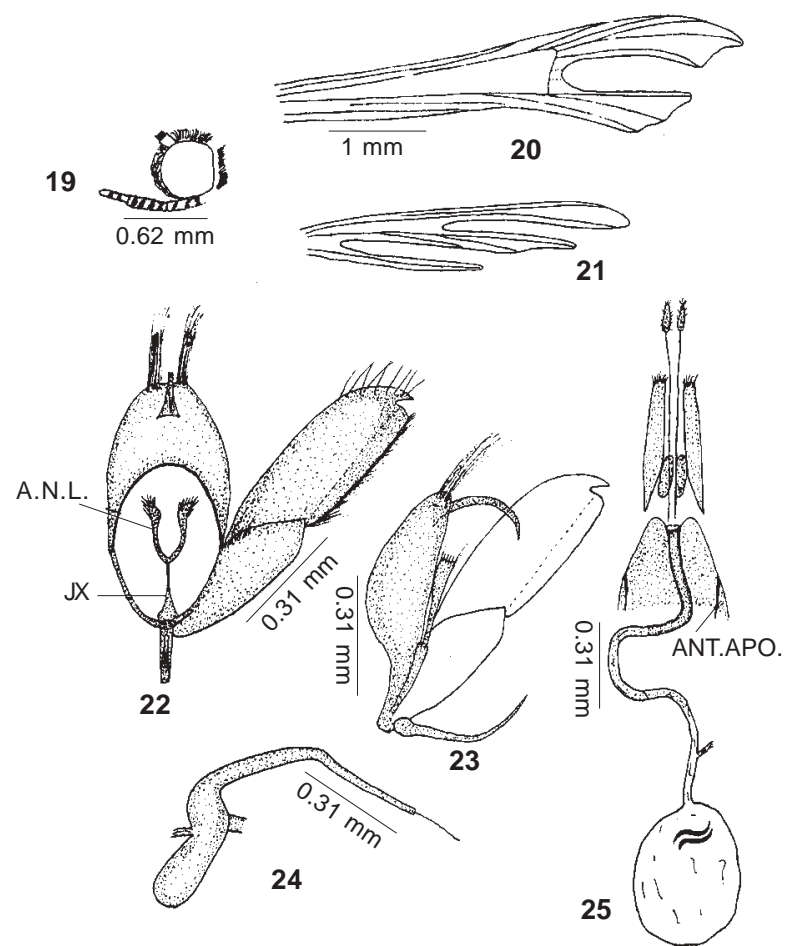

Figures 19-25. Lantanophaga anellatus sp. nov.

19 - Labial palpus; 20 - Forewing venation;

21 - Hindwing venation; 22 - Male genitalia (ventral view);

23 - Male genitalia (lateral view); 24 - Aedeagus; 25 - Female genitalia (ventral view)

pusillidactyla Walker is represented by another species i.e., $L$. longiductus Gibeaux (Malagasy Rep.), whose status in this genus is still uncertain on the global basis. In India, the genus is reported by its type-species. During the course of present studies, a phenon comprising one hundred and five specimens (63 males, 44 females) showing some colour variation (light greyish-fuscous, dark greyish-fuscous and ochreous-fuscous) has been taxonomically treated in considerable details. As many as 21 specimens ( 7 from each locality) have been dissected and found to be conspecific genitalically. The present species though closely allied to L. pusillidactyla (Walker) yet is drastically different from it in shape of the cucullus and more importantly in shape of the aedeagus. The latter is short and broad in L. pussilidactyla, whereas long and slender with tip acute in the present species, which has not been named so far. Accordingly, its name is proposed as Lantanophaga anellatus sp. nov. Surprisingly, the position of labial palpus has been found to be little varying in this species. The third segment may be drooping or straight in some of the individuals but their conspecificity is upheld by their genitalia. Hence this character needs to be carefully evaluated.

\section{Amblyptilia Hübner}

Amblyptilia Hübner, [1825] 1816, Verz. Bekannter Schmett.: 430. Amplyptilia (sic) Hübner, [1825] 1816, Verz. Bekannter Schmett.: 430. Amblyptilus Wallengren, 1862, K. Svenska Vetensk Akad. Handl. (N.F.) 3 (7): 13. (unjustified emend.)

Type-species: Alucita acanthadactyla Hübner, [1813] 1796, 
Samml. Eur. Schmett. 9: pl. 5, figs. 23, 24, by subsequent designation by Tutt, 1905, Entomologist's Rec. J. Var. 17: 35 (but cited as Amplyptilia (sic)).

\section{Amblyptilia forcipeta Zeller}

Pterophorus forcipeta Zeller, 1867, Stett. Ent. Ztg., 28: 412.

Material examined: 1 male, 24.ix.1973, Solan, Himachal Pradesh, 1400m; 1 male, 2 females, 12-14.ix.1999, UHF, Nauni, Himachal Pradesh, $1360 \mathrm{~m}$.

Distribution: India (Sikkim, Darjeeling) (Fletcher, 1931).

\section{Diagnostic features}

Male genitalia (Figs. 26-29): Uncus long, slender, curved, gradually narrowing, tip pointed, beset with backwardly directed dense fine setae; tegumen moderate, shoulders rounded, somewhat bilobate; vinculum reduced; saccus broad, platelike, distally with a row of small setae, the latter arranged comblike; valvae symmetrical, somewhat semi-oval, broadest in middle, costa sinuate, sacculus long, narrow, reaching almost apex, ventral margin with a row of long dense hair, cucullus reduced, undifferentiable, top somewhat bird head-like, ventral margin produced into a small beak, a patch of hair in centre of valva; aedeagus stout, moderate in size, strongly curved, somewhat narrowing apically, coecum well developed, ductus ejaculatorius opposite to caulis.

Female genitalia (Fig. 30): Papillae anales and posterior apophyses not differentiable; ostium bursae broad, laterally placed; seventh sternite sclerotized in the form of lamella

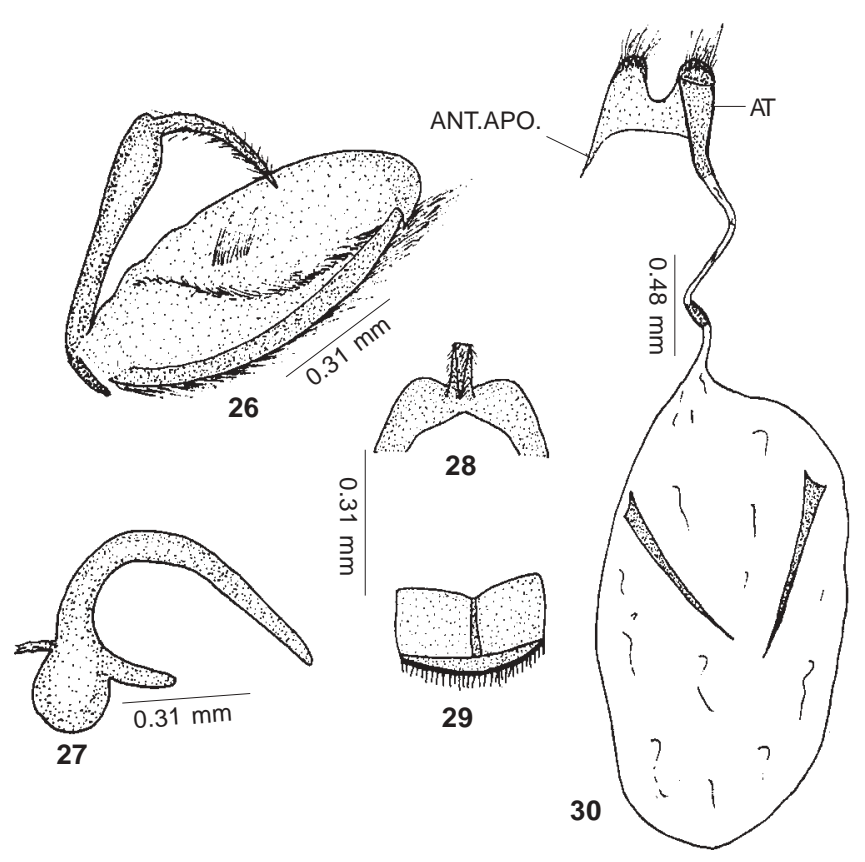

Figures 26-30. Amblyptilia forcipeta Zeller. 26 - Male genitalia (lateral view); 27 - Aedeagus; 28 - Uncus (ventral view); 29 - Saccus; 30 - Female genitalia (ventral view) antivaginalis, produced into anterior apophyses; antrum long, tube-like; ductus bursae long, slender, gradually narrowing towards corpus bursae, a small sclerotized patch in the anterior half; corpus bursae very large, globular in shape, with two large, straight horn-like signae.

Alar expanse: Male and female 18-19mm.

\section{Larval host plant: Unknown}

Remarks: The species forcipeta of the genus Amblyptilia Hübner is the only species known from India, out of a total of 25 species otherwise recorded from the Holarctic, Afrotropical, Neotropical and Indo-Australian regions (Gielis, 1993). It has been observed that the male genitalia of species, under reference, is quite conspicuous in having bird head-like valva (cucullus), slightly bilobate tegumen and the saccus being bordered by a brush of hair arranged in a comb-like fashion. Regarding distribution, the species is reported as additional record from northwestern India as the same has earlier been reported from Sikkim and Darjeeling (northeastern India) by Fletcher (1931) under the name of Platyptilia forcipeta.

\section{Gypsochares Meyrick}

Gypsochares Meyrick, 1890, Trans., Ent. Soc. Lond., 1890: 488. Type-species: Pterophorus batodactyls Zeller, 1850: Stettin. Ent. Ztg, 28: 414, by original designation.

\section{Gysochares catharotes Meyrick}

Gysochares catharotes Meyrick, 1908, Trans., Ent. Soc. Lond. 1907: 491.

Material examined: 3 males, 25-26.ix.1973, Chambaghat, Solan district, Himachal Pradesh, 1200m.

Distribution: India (Khasi Hills, Cherrapunji, Sikkim, Kumaon, Bhim Tal, Muktesar), ? Pakistan (Fletcher, 1931; Gielis, 1993).

\section{Diagnostic features}

Male genitalia (Figs. 31-33): Uncus well developed, bseset with forwardly directed fine and dense setae, the latter directed anteriorly, at right angle to tegumen, tip curved, pointed; tegumen narrow, slightly arched; vinculum broad, U-shaped, with well developed saccus, the latter directed caudad, dentate distally; valvae asymmetrical, each valva with costa straight, sacculus moderately sized, right valva with cucullus bilobed, upper lobe again bipartite, produced into cucullar spines, lower lobe broad, comparatively less sclerotized, rather membranous, left valva also with bilobed cucullus, upper lobe produced into cucullar spine, latter long, slender, finger like, lower lobe pointed, relatively less sclerotized; aedeagus moderate in size, somewhat narrowing apically, slightly curved, tip abruptly narrow, strongly curved.

Female genitalia: Not examined.

Alar expanse: Male 13-14mm. 


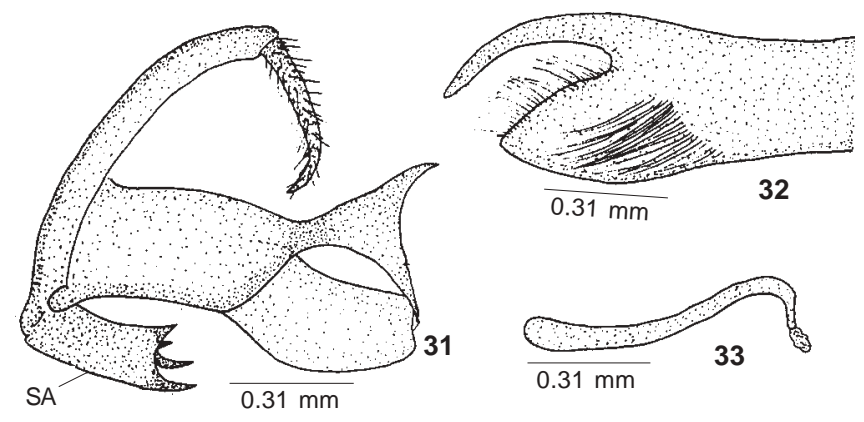

Figures 31-33. Gypsochares catharotes Meyrick 31 - Male genitalia (lateral view); 32 - Left valva; 33 - Aedeagus

\section{Larval host plant: Unknown}

Remarks: In having asymmetrical valvae with each valva modified into a cucullar spine, the species broadly obeys the diagnosis of the genus Gypsochares (type-species: Pterophorus baptodactylus Zeller (Italy)) recently revised by Gielis (1993). Besides type-species, the genus is represented by five more species i.e., G. bigoti Gibeaux and Nel (France), $G$. nielswolffi Gielis and Arenberger (Portugal), G. kukti Arenberger (India), G. catharotes Meyrick (?Pakistan) and G. aulotes Meyrick (Republic S. Africa) (Gielis, loc. cit.). The latter worker, somehow or the other, has mentioned Pakistan as the typelocality of G. catharotes, whereas, according to Fletcher (1931) it is India (Khasi Hills, Assam). Apart from the type-locality, the species has been reported from Shillong, Cherrapunji, Sikkim, Kurseong (northeastern India) and Kumaon, Bhimtal and Muktesar (northwestern India). The species is reported for the second time from northwestern India.

\section{Exelastis Meyrick}

Exelastis Meyrick, 1907, J. Bombay Nat. Hist. Soc., 17: 730. Type-species: Aciptilia atomosa Walsingham, 1886, Proc. Zool. Soc. Lond. 1886: 885, by original designation.

\section{Discussion}

The genus Exelastis Meyrick comprises a heterogenous assemblage of twelve species from various parts of the world. The valvae in the male genitala of some of the species show asymmetry, while in some others, the valvae are symmetrical in shape (Gielis, 1993). However, the type-species i.e., Exelastis atomosa (Walsingham) of the genus possesses asymmetrical valvae (slide no. 5993, NHM, London) and this is more pronounced in size of the saccular spines. The saccus is well developed and bilobate. Three most common species i.e., Exelastis atomosa (Walsingham), E. pumilio (Zeller) and E. phlyctaenias (Meyrick) have usually been confused/ misidentified with each other owing to their superficial morphological similarity and overlapping of distribution (Fletcher, 1909, 1931; Gielis, 1993). The present sample comprising 152 individuals (108 males, 44 females) has been segregated into two species, which have been identified as Exelastis pumilio and E. phlyctaenias after a series of 30 dissections (22 males, 8 females) of variable individuals.
Exelastis phlyctaenias Meyrick

Marasmarcha phlyctaenias Meyrick, 1911, J. Bombay Nat. Hist. Soc., 21: 106.

Material examined: 1 male, 6.ix.1998, 1 female, 29.ix.1998, 1 male, 9.ix.1998, 1 male, 29.ix.1998, PUP, Patiala, Punjab, 250m.

Distribution: India (Coorg); Sri Lanka (Fletcher, 1931).

\section{Diagnostic features}

Male genitalia (Figs. 34-36): Uncus broad, fleshy, somewhat conical, furnished with backwardly directed strong dense setae, tip rounded; tuba analis somewhat developed; tegumen thin, narrow; vinculum reduced; saccus bilobate, well developed, inverted v-shaped in ventral view; valvae somewhat asymmetrical, each valva narrow basally, strongly clavate distally, costa convex in both valvae, sacculus asymmetrical, produced into saccular spines, left spine short, right saccular spine thin, long, pointed, cucullus symmetrical, strongly clavate, dorsal margin strongly convex, apex rounded, with a group of very dense hair ventro-distally, remaining valva sparsely hairy at inner surface; aedeagus moderate, gradually curved, both lips pointed apically.

Female genitalia (Fig. 37): Papillae anales flat; anterior apophyses absent, posterior apophyses moderately long; ostium bursae centrally placed; antrum slightly broad, cup shaped; ductus bursae moderate in size, gradually widening towards corpus bursae; corpus bursae large, globular in shape, signum absent; ductus seminalis entering almost in middle of ductus bursae.

Alar expanse: Male and female 15-16mm.

Larval host plant: Anarcardium occidentale (Fletcher, 1931).

Remarks: The identification of the species has been attempted
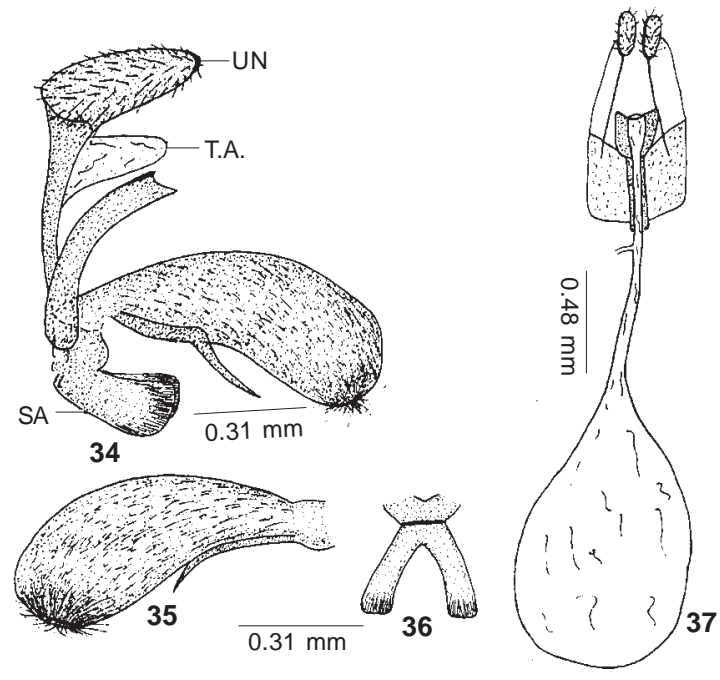

Figures 34-37. Exelastis phlyctaenias Meyrick 34 - Male genitalia (lateral view); 35 - Left valva; 36 - Saccus; 37 - Female genitalia (ventral view) 
after tallying it with the description given by Meyrick (1911) and information sought from Gielis (pers. comm.). After comparison of the male genitalia with that of the Exelastis atomosa (Walsingham) (slide no. 5993), it has been inferred that E. phlyctaenias (Meyrick) is an independent species, which differs from the former species in shape of the cucullus and the aedeagus. The cucullus is abruptly expanded in the E. atomosa, whereas, it is gradually expanded in E. phlyctaenias. Also the aedeagus is straight in E. atomosa but slightly curved in $E$. phlyctaenias. However, Gielis (1993) has listed E. phlyctaenias as a synonym of E. atomosa in this publication.

\section{Exelastis pumilio Zeller}

Mimeseoptilus pumilio, Zeller, 1873, Verh. Z. B. Ges. Wien, 23: 324.

Material examined: 2 males, 4-7.iii.1998, 2 males, 1 female, 1213.iv.1998, 3 males, 2 females, 14.vii.1998, 12 males, 4 females, 116.ix.1998, 6 males, 2 females, 2-28.x.1998, 6 males, 6-12.xi.1998, 1 female, 12.i.1999, 7 males, 3 females, 2-18.iii.1999, 7 males, 4 females, 4-25.vii.1999, 14 males, 5 females, 1-26.ix.1999, 25 males, 10 females, 3-25.x.1999, 5 males, 3 females, 14-30.xi.1999, PUP, Patiala, Punjab, 250m; 2 males, 29.vii.2001, Renuka Lake, Sirmour district, Himachal Pradesh, 740m; 2 males, 24.ix.1973, Solan, Himachal Pradesh; 5 males, 3 females, 25.ix.1973, Chambaghat, Himachal Pradesh; 1 male, 27.v.2001, KV, Palampur, Himachal Pradesh; 4 males, 3 females, 2-8.ix.1973, FRI, Dehradun, Uttaranchal, 700m; 1 male, 3 females, 20.ix.1973, Chandigarh(UT)

Distribution: Cosmopolitan (Fletcher, 1931; Gielis, 1993).

\section{Diagnostic Features}

Male genitalia (Figs. 38-39): Uncus small, bilobate; a sclerotized, setosed area representing socii; tegumen well developed, high, pointed, shoulders oblique; vinculum reduced, weak; saccus small, bilobate; valvae symmetrical, basally narrow, costa
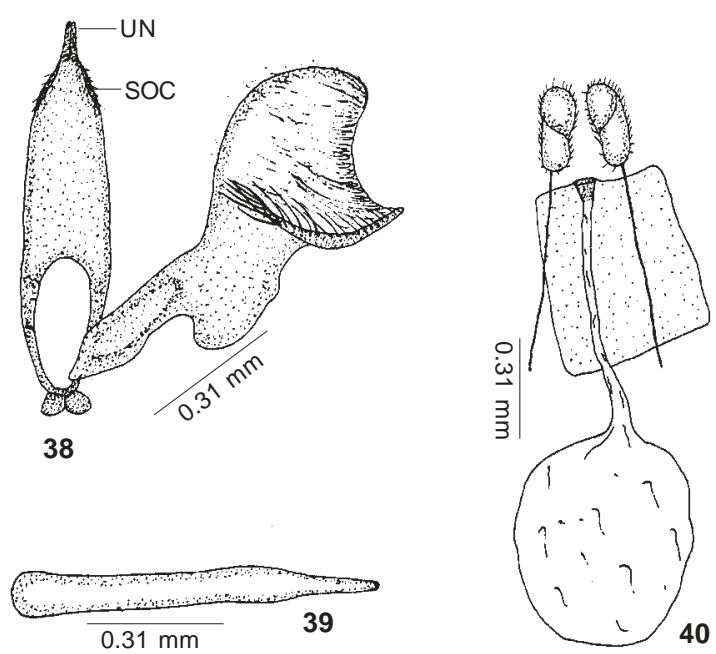

Figures 34-37. Exelastis pumilio Zeller 38 - Male genitalia (ventral view); 39 - Aedeagus; 40 - Female genitalia (ventral view) straight, sacculus deeply constricted medially, ending in a rounded lobe, cucullus well developed, broad, dorso-distally rounded, top concave, clefted, dorsal lobe rounded, ventral somewhat pointed, inner surface with long dense hair, ventral margin with long strong setae, basal 5-7 setae longer; aedeagus straight, long, somewhat dilated beyond middle, apex roundpointed.

Female genitalia (Fig. 40): Papillae anales flat, broad; anterior apophyses absent, posterior apophyses very long; ostium bursae centrally placed, antrum small, ductus bursae long, slender, slightly expanding distally, corpus bursae moderate in size, signum absent.

Alar expanse: Male and female 11-16mm.

Larval host plants: Oxalis, Ambrosia artemisiaefolia, Desmodium, Alysicarpus vaginalis (Fletcher, 1931).

Remarks: Exelastis pumilio is cosmopolitan in distribution and is one of the most common specis of the genus Exelastis Meyrick.

\section{Tomotilus Yano}

Tomotilus Yano, 1961, Mushi, 35: 87

Type-species: Tomotilus saitoi Yano, 1961, ibidem, 35: 88, textfigs. 1,2, by original designation.

\section{Tomotilus saitoi Yano}

Tomotilus saitoi Yano, 1961, Mushi, 35: 88, text-figs. 1,2.

Material examined: 1 male, 27.vi.2001, FRH, Chohal, Hoshiarpur district, Punjab, 400m

\section{Distribution: India}

\section{Diagnostic features}

Male genitalia (Fig. 41): Uncus well developed, fleshly, conical, densely hairy, at right angle to tegumen; tegumen reduced, narrow, top somewhat produced; vinculum reduced, valva large and broad, somewhat triangular in outline, costa concave, medially with a small protuberance, sacculus strongly convex

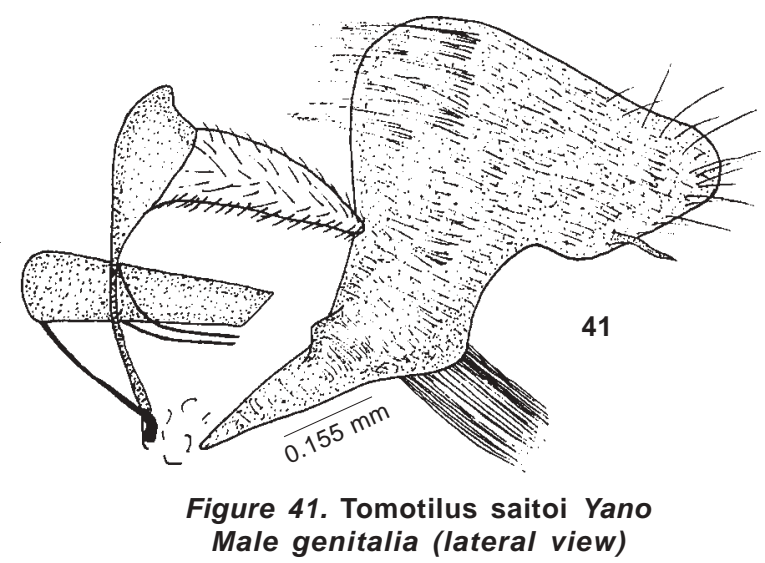


in middle, with a group of long hair medially, cucullus very broad, dorso-distally expanded, form a round lobe, ventrally delimited by a neck, ventro-medially with a long and thin beaklike structure, ventro-distally produced into a small lobe, marginally with a sparse row of fine setae, inner surface of valva with long dense hair throughout; aedeagus small, straight, stout, somewhat conical, ventro-lateraly supported by two sclerotized arms, upper lip pointed.

Female genitalia: Not examined.

Alar expanse: Male $12 \mathrm{~mm}$.

\section{Larval host plant: Unknown}

Remarks: Due to some unique characters (viz., male genitalia with well developed uncus and remarkably broad valva), Yano (1961) has proposed a new genus Tomotilus with T. saitoi Yano as its type-species from Japan. The presently dissected specimen truly conforms to the characterization of this monotypic genus Tomotilus Yano and is, accordingly, identified as Tomotilus saitoi Yano. This is the first record of this taxon from a country other than Japan (Gielis, 1993). The species appears to be quite rare in the northwestern India.

\section{Procapperia Adamczewski}

Procapperia Adamczewski, 1951, Bull. Br. Mus. Nat. Hist. (Ent.) 1:338.

Type-species: Oxyptilus maculatus Constant, 1865, Annls Soc. Ent. Fr. (4) 5: 193, pl. 7, fig. 9, by original designation.

\section{Procapperia pelecyntes Meyrick}

Oxyptilus pelecyntes Meyrick, 1907, Trans. Ent. Soc. Lond., 1907: 477.

Material examined: 1 male, 12.iv.1999, UHF, Nauni, Solan district, Himachal Pradesh, 1360m.

Distribution: India (Khasi Hills), Sri Lanka, China (Adamczewski, 1951).

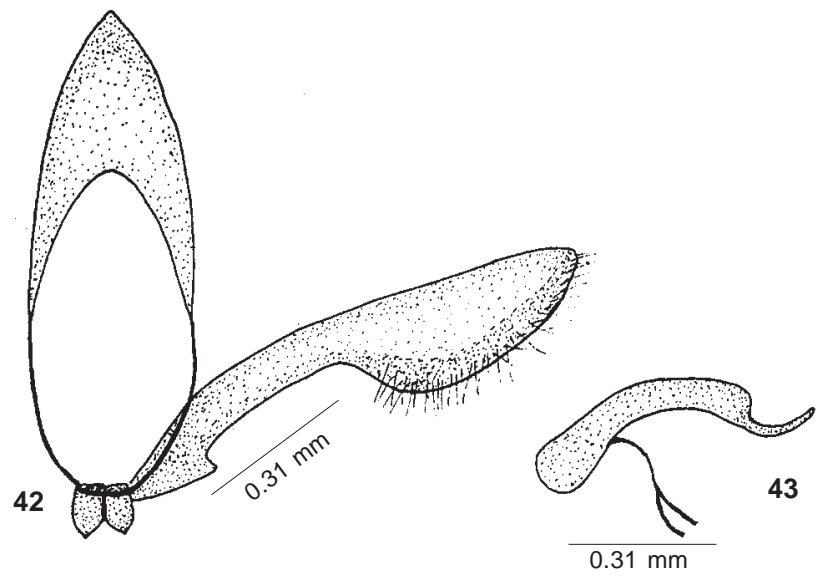

Figures 42-43. Procapperia pelecyntes Meyrick 42 - Male genitalia (ventral view); 43 - Aedeagus

\section{Diagnostic features}

Male genitalia (Figs. 42-43): Uncus absent; tegumen narrow, raised, top well developed, somewhat conical, pointed; vinculum weak; saccus bilobate, lobes pointed distally; valva moderate in size, rather narrow, costa and sacculus relatively reduced, cucullus expanded, broad, separable by a long narrow neck, dorsal margin straight, ventral margin strongly convex, narrowing apically, apex more or less rounded, inner surface particularly towards ventral margin with small dense hair; aedeagus short, broad, strongly sinuate, gradually curved in middle, tip abruptly narrowing and curved dorsally, tip pointed, vesica without cornuti.

Female genitalia: Not examined.

Alar expanse: Male $14 \mathrm{~mm}$.

Larval host plant: Scutelloria discolor (Fletcher, 1921).

Remarks: Adamczewski (1951) while proposing the genus Procapperia with Oxyptilus maculata Constant (South Croatia) as its type-species dealtwith four more species viz., $P$. linariae (Chrétein) (Morocco), P. croatica Adamczewski (South Croatia), P. anatolica (Caradja) (Asia minor) and P. pelecyntes (Meyrick) (India, Sri Lanka) from the respective part of the world. Recently, Arenberger (1988) reported a new species i.e., P. orientalis from Kashmir in northwestern India. Out of the two species i.e., $P$. pelecyntes (Meyrick) and $P$. orientais Arenberger, the former could be collected from northwestern India during present surveys. The species seems to be quite rare in the area, under reference.

\section{Megalorrhipida Amsel}

Megalorrhipida Amsel, 1935, Mitt. Zool. Mus. Berl. 20: 293. Megalorhipida (sic) Amsel, 1935, Mitt. Zool. Mus. Berl. 20: 293.

Type-species: Megalorrhipida palaestinensis Amsel, 1935, ibidem, 20: 293, pl. 10, fig. 27; pl. 18, figs. 79, 80, by monotypy.

\section{Discussion}

According to Gielis (1993), the genus Megalorrhipida Amsel is represented by three species i.e., $M$. defectalis Walker (typespecies), M. pseudodefectalis Gielis and M. dulcis (Walsingham) and is distributed in pantropical and subtropical regions of the world. The status of the latter species in this genus is still uncertain (Gielis, 1993).

During the course of present studies, besides the type-species, two more unnamed species have been taxonomically treated. The male genitalia of both the unnamed species broadly conforms to the male genitalia of the type-species. The uncus is large, expanded and fleshy with backwardly directed setae and the valvae are symmetrical and somewhat oval in shape. The congeneric nature of these species is clearly established on the basis of their male genitalic structures. Further, this has been possible for one of the unnamed species in respect of some female genitalic characters, as well. Like type-species, the papillae anales are somewhat triangular in shape and the 
posterior apophyses are very long and the ostium is centrally placed. The corpus bursae possesses two small bean-shaped signae. However, this could not be confirmed for the other unnamed species for want of female specimen. The congeneric nature of all the three species is also evident from the absence of veins $R_{1}, R_{5}, C u A_{1}$ and $C u A_{2}$ of the forewing and $S c+R_{1}, M_{1}$, $\mathrm{M}_{2}$ and $\mathrm{CuA}_{2}$ of the hindwing. The vertex is also studded with modified scales in all the three species. In view of this, besides reporting the type-species, Megalorrhipida defectalis (Walker), two other new species have been described here from northwestern India.

\section{Megalorrhipida paradefectalis sp. nov.}

\section{Material examined}

Holotype: Male, 24.ix.1973, Solan, Himachal Pradesh, 1300m

Etymology: The name of the species is derived and proposed as Megalorrhipida paradefectails sp. nov. from the typespecies i.e., M. defectalis Walker to which it is rather more allied.

\section{Diagnostic features}

Male: Vertex and frons covered with whitish grey scales, with slight ochreous tinge, vertex with modified erect scales; antenna filiform, whitish-grey; labial palpus porrect, two times diameter of eye, greyish-white, third segment pointed (Fig. 44); thorax greyish-white; forewing clefted bifid, both lobes acute, cleft slightly deeper than middle, greyish-white with a few very fine dark specks, fringes whitish with few grey and brown cilia; hindwing trifid, all lobes acute, fringes whitish-grey; legs pale; abdomen greyish-white.

Wing venation (Figs. 45-46): Forewing with Sc ending beyond
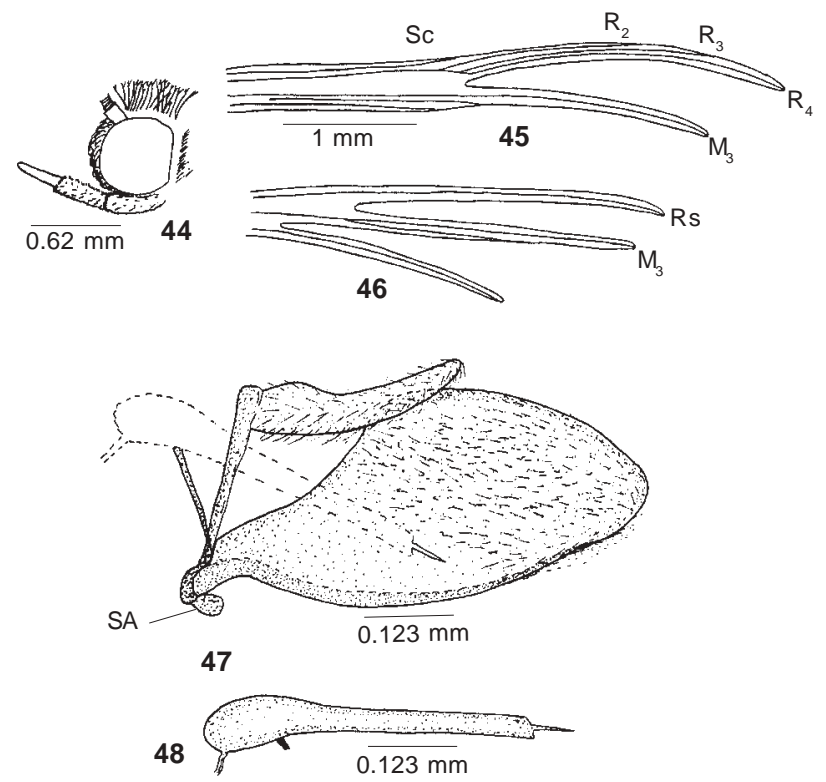

Figures 44-48. Megalorrhipida paradefectalis sp. nov. 44 - Labial palpus; 45 - Forewing venation; 46 - Hindwing venation; 47 - Male genitalia (lateral view); 48 - Aedeagus one-third of costal margin, $\mathrm{R}_{1}$ and $\mathrm{R}_{5}$ absent, $\mathrm{R}_{2}, \mathrm{R}_{3}$ and $\mathrm{R}_{4}$ present, all veins separate, $\mathrm{R}_{4}$ ending at apex of first lobe, discocellulars, $M_{1}$ and $M_{2}$ absent, $M_{3}$ ending at apex of second lobe, $\mathrm{CuA}_{1}, \mathrm{CuA}_{2}$ and $\mathrm{CuP}$ absent, two anal veins $(1 \mathrm{~A}+2 \mathrm{~A}$ and $3 \mathrm{~A})$ present; hindwing with $\mathrm{Sc}+\mathrm{R}_{1}$ absent, Rs ending at apex of first lobe, $M_{1}$ and $M_{2}$ absent, $M_{3}$ ending at apex of second lobe, $\mathrm{CuA}_{1}$ arising from point of lower angle of cell, $\mathrm{CuA}_{2}$ and $\mathrm{CuP}$ absent, third lobe with only one anal vein $(1 \mathrm{~A}+2 \mathrm{~A}), 3 \mathrm{~A}$ absent.

Male genitalia (Figs. 47-48): Uncus large, fleshy, beset with backwardly directed setae, dorsal margin slightly concave, top somewhat pointed, at right angle to tegumen; tegumen narrow; vinculum reduced, saccus bilobed; valvae symmetrical, narrow at base, semi-oval, broadest in middle, costa slightly concave, saccular margin narrow, arched, reaching almost near apex, cucullus broad, gradually narrowing towards apex, dorsal margin oblique, apex rounded, ventro-distally produced, inner surface of valva with very fine but dense hair; aedeagus long, slender, almost straight, base somewhat globular, tip abruptly pointed, needle like, coecum very small, ductus ejaculatorius opening ventrally.

Female genitalia: Not examined.

Alar expanse: Male $10 \mathrm{~mm}$.

\section{Larval host plant: Unknown}

Remarks: Megalorrhipida paradefectalis sp. nov. is closely allied to the type-species viz., M. defectalis as well as M. gielisi sp. nov. but these can be separated on the basis of the wing maculation besides size and shape of the aedeagus, uncus and the valvae in the male genitalia.

\section{Megalorrhipida defectalis Walker}

Pterophorus defectalis Walker, 1864, List Specimens lepid. Insects Colln Br. Mus., 30: 943.

Material examined: Punjab: Dist. Patiala, PUP, 250m, 17.xi.1999, one male, Dist. Hoshiarpur; FRH, Chohal 400m, 27.vi.2001, one female.

Distribution: Cosmopolitan (Gielis, 1993).

\section{Diagnostic feature}

Male genitalia (Figs. 49-50): Uncus large, fleshy, studded with backwardly directed, dense hair, dorsal margin strongly concave, top rounded at right angle to tegumen; tegumen narrow, moderately high; vinculum reduced, saccus bilobed, clubshaped, membranous; valvae symmetrical, roughly oval in outline, costa straight, saccular margin moderately broad, narrowing apically, oblique, ventrally straight throughout; cucullus broad, round, poorly delimited by a slightly narrow neck, dorsal margin round, ventro-distally somewhat produced, inner margin with very fine dense hair; aedeagus moderately long, slender, almost straight, somewhat globular basally, tip straight. 


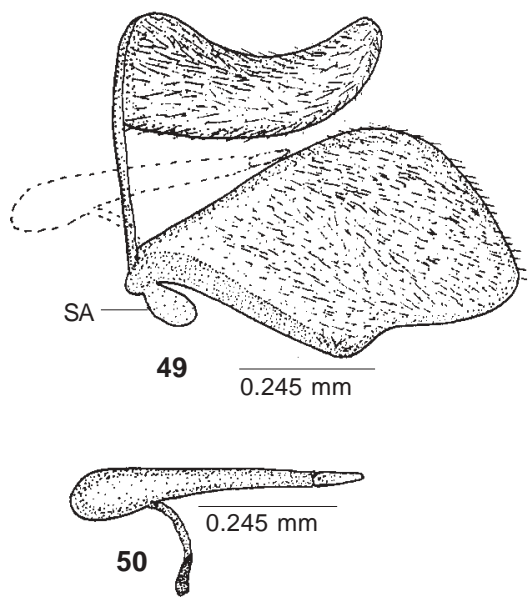

Figures 49-51. Megalorrhipida defectalis Walker. 49 - Male genitalia (lateral view); 50 - Aedeagus; 51 - Female genitalia (ventral view)

Female genitalia (Fig. 51): Papillae anales small, somewhat triangular, anterior apophyses absent; posterior apophyses very long; seventh sternite moderately sclerotized; lamella postvaginalis bilobate; ostium bursae centrally placed; antrum narrow; ductus bursae long, slender; corpus bursae large, with two small and bean shaped signae.

Alar expanse: Male and female 14-15mm

Larval host plant: Boerhaavia repens (Fletcher, 1931).

Remarks: The type-species i.e., M. defectalis (Walker) has earlier been reported from Coimbatore, Poona, Pusa and Chapra (Bengal) (Fletcher, 1931). The present collection adds an additional distributional locality from the North West India.

\section{Megalorrhipida gielisi sp. nov.}

\section{Material examined}

Holotype: Male, 27.ix.1973, Chambaghat, Solan district, Himachal Pradesh, 1200m.

Paratypes: 2 males, 1 female, 20.ix.1977, PU, Chandigarh, 300m.

Etymology: The species is named after the name of a pterophorid worker Cees Gielis of The Netherlands. He has been concentrating on the plume moths for the last 25 years.

\section{Diagnostic features}

Male, Female: Vertex and frons pale ochreous, vertex with erect modified scales; antenna filiform, pale ochreous, labial palpus porrect, moderate in size, two times diameter of eye, second segment whitish, third segment pointed, pale in colour (Fig. 52); thorax covered with pale ochreous scales dorsally, whitish ventrally; forewing clefted bifid, cleft almost upto middle, both lobes narrow, acute, pale ochreous with mixed scales of whitish and brownish colour, clefted part darker than proximal half, fringes ochreous brown, with few black cilia; hindwing clefted trifid, all lobes acute, ochreous brown, fringes pale and light
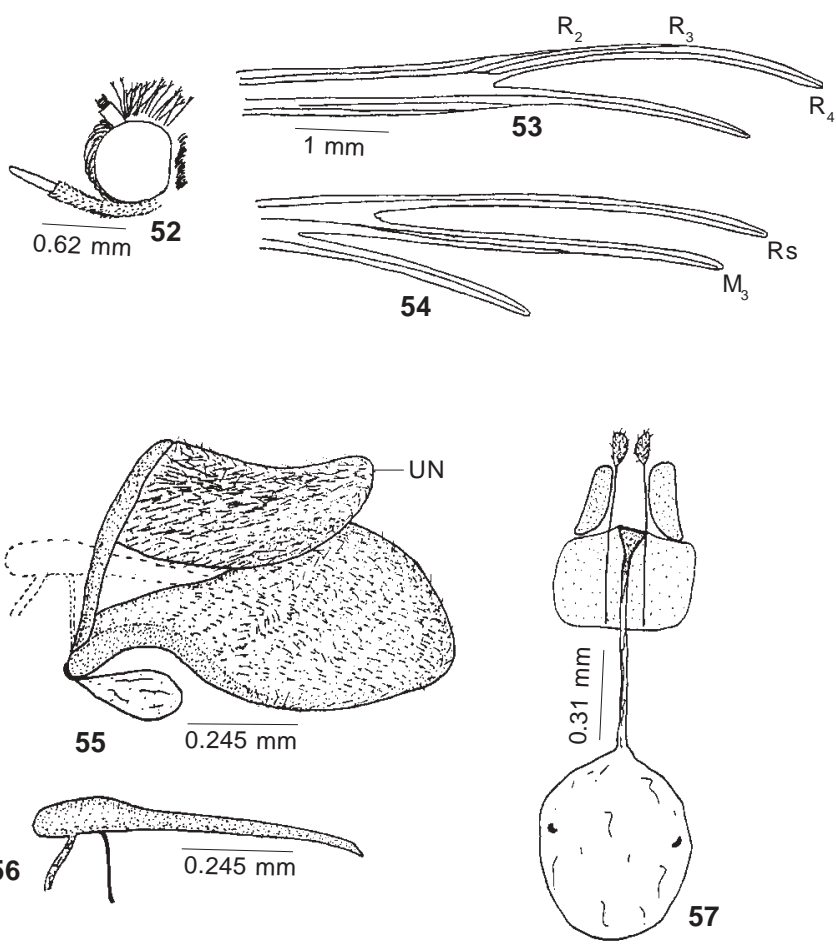

Figures 52-57. Megalorrhipida gielisi sp. nov. 52 - Labial palpus; 53 - Forewing venation;

54 - Hindwing venation; 55 - Male genitalia (ventral view); 56 - Male genitalia (lateral view); 57 - Aedeagus; 58 - Female genitalia (ventral view)

grey; legs pale ochreous; abdomen whitish ventrally with slight ochreous tinge.

Wing venation (Figs. 53-54): Forewing with Sc ending beyond one-third of costal margin, $\mathrm{R}_{1}$ and $\mathrm{R}_{5}$ absent, $\mathrm{R}_{2}, \mathrm{R}_{3}$ and $\mathrm{R}_{4}$ present, all veins free, $\mathrm{R}_{4}$ ending at apex of first lobe, discocellulars, $M_{1}$ and $M_{2}$ absent, $M_{3}$ ending at apex of second lobe, $\mathrm{CuA}_{1}, \mathrm{CuA}_{2}$ and $\mathrm{CuP}$ absent, two anal veins $(1 \mathrm{~A}+2 \mathrm{~A}$ and $3 \mathrm{~A}$ ) present; hindwing with $\mathrm{Sc}+\mathrm{R}_{1}$ absent, Rs ending at apex of first lobe, $M_{1}$ and $M_{2}$ absent, $M_{3}$ ending at apex of second lobe, $\mathrm{CuA}_{1}$ arising from point of lower angle of cell, $\mathrm{CuA}_{2}$ and $\mathrm{CuP}$ absent, third lobe with only one anal vein $(1 \mathrm{~A}+2 \mathrm{~A}), 3 \mathrm{~A}$ absent.

Male genitalia (Figs. 55-57): Uncus large, fleshy, expanded, somewhat triangular, furnished with backwardly directed dense fine hair, dorsal margin concave, top rounded, at right angle to the tegumen; tegumen narrow, moderately high, vinculum weak; saccus bilobed, club-shaped, membranous; valvae symmetrical, roughly oval in outline, costa straight, slightly concave, saccular margin moderate, narrow, oblique, basally strongly concave, cucullus broad, round, neck absent, dorsal margin round, ventro-distally somewhat produced, inner surface with very fine but dense hair; aedeagus long, slender, almost straight, gradually narrowing apically, lower lip pointed, coecum moderate, ductus ejaculatorius enters from ventral side near caulis.

Female genitalia (Fig. 58): Papillae anales small, somewhat 
triangular; anterior apophyses wanting, posterior apophyses quite long; seventh sternite moderately sclerotized; lamella postvaginalis bilobed; ostium bursae wide, centrally placed; antrum funnel-shaped; ductus bursae long, slender; corpus bursae large, globular in shape, with two small bean-shaped signae.

Alar expanse: Male and female 13-14mm.

\section{Larval host plant: Unknown}

Remarks: Megalorrhipida gielisi sp. nov. can be easily distinguished from $M$. defectalis as well $M$. paradefectalis sp. nov. on the basis of the structure of the uncus and shape of the aedeagus in the male genitalia.

\section{Prichotilus Gen. nov.}

Type-species: Trichoptilus bidens Meyrick, 1930, Exot. Microlepid. 3: 564.

Diagnosis: Labial palpus long, more than two times diameter of eye, strongly upcurved, tip reaching beyond vertex, third segment almost as long as second (Fig. 58); forewing bifid, both lobes acute; hindwing trifid, all lobes acute; forewing with $\mathrm{R}_{1}, \mathrm{R}_{3}$ and $\mathrm{R}_{5}$ absent, $\mathrm{R}_{2}$ and $\mathrm{R}_{4}$ present, separate, $\mathrm{Cu} \mathrm{A}_{1}$ and $\mathrm{CuA}_{2}$ absent (Fig. 59); hindwing with each lobe having one vein, $\mathrm{Sc}+\mathrm{R}_{1}, \mathrm{M}_{1}, \mathrm{M}_{2}, \mathrm{CuA}_{1}, \mathrm{CuA}_{2}$, and $\mathrm{CuP}$ absent, $\mathrm{Rs}$ in the first lobe, $\mathrm{M}_{3}$ in the second lobe, third lobe with only one anal vein $(1 \mathrm{~A}+2 \mathrm{~A})$ (Fig. 60); male genitalia with uncus somewhat conical, fleshy, with backwardly directed setae, top rounded apically; saccus absent; valva broad, cucullus well developed, broad, top bilobed, upper lobe long, slender, finger-like, lower lobe more or less triangular.

Prichotilus bidens Meyrick Comb. nov.

Trichoptilus bidens Meyrick, 1930, Exot. Microlepid. 3: 564.

Material examined: 5 males, 12-13.iv.1999, Renuka Lake, Sirmour district, Himachal Pradesh, 740m.

Distribution: India (Khasi Hills)

\section{Diagnostic features}

Male genitalia (Fig. 61): Uncus moderate in size, somewhat conical, fleshy, with backwardly directed setae rounded apically; tuba analis traceable, slightly sclerotized, conical; tegumen very small, slender; vinculum reduced; saccus absent; valva broad, costa and sacculus reduced, cucullus well developed, broad, top bilobed, upper lobe in the form of long, slender and curved finger-like projection, lower lobe somewhat triangular in shape, with a small projection apically; aedeagus small, straight, membranous, slightly globular basally, gradually narrowing apically.

Female genitalia: Not examined.

Alar expanse: Male 10-11mm

\section{Larval host plant: Unknown}

Remarks: Walsingham (1880) proposed the genus Trichoptilus with T. pygmaeus Walsingham as its type-species from California. Though workers like Meyrick (1886) and Fletcher (1929, 1931) have followed this generic name yet the genus has not been properly diagnosed till Gielis (1993) redescribed the same in considerable detail. While doing so, the author (Gielis, 1993) besides placing a congeneric species i.e., T. potentellus Lange under this genus has categorically remarked that the status of other 20 species described under this genus remain uncertain till date. Out of these, Meyrick (1907, 1913, 1930) earlier had described species T. pelias (Coorg, Kanara, Khasi Hills), T. archeodes (N. Kanara) and T. bidens (Khasi Hills) from the respective locality/ies from India. The presently collected sample was identified as Trichoptilus bidens Meyrick from the brief description (without genitalia) given by Meyrick (1930).

Further, in order to solve the uncertain status, Gielis (1993) has transferred the species viz., Trichoptilus defectalis Walker, $T$. paludicola Fletcher and T. wahlbergi (Zeller) to Megalorhipida Amsel, Buckleria Tutt and Crombrugghia Tutt, respectively. The identity of the present species as T. bidens has been confirmed from the aforesaid worker (pers. comm.), who has listed it along those species having their generic status not clear, so far (Gielis, 1993). The critical examination of the male genitalia of bidens reveals that it differs drastically from the male genitalia of the type-species i.e., Trichoptilus pygmaeus Walker of the genus Trichoptilus Meyrick. Unlike the typespecies, the uncus is well developed, conical and fleshy and the vinculum is simple without saccus in T. bidens. The uncus is obsolete and the vinculum is bilobate with a vesicular saccus in T. pygmaeus Walker. In addition to this, the valva is more or less triangular with distal portion, representing cucullus being
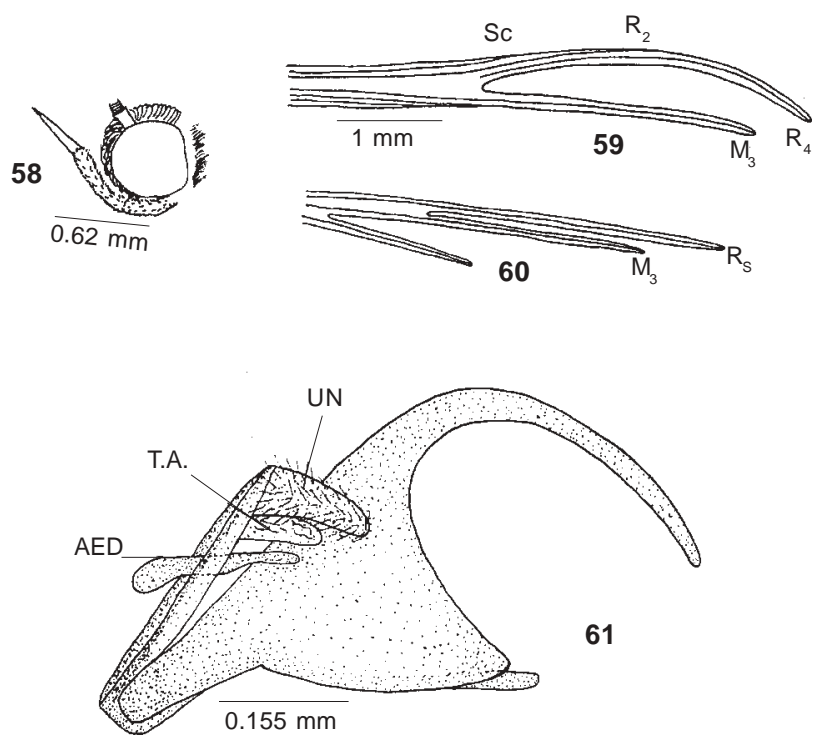

Figures 58-61. Prichotilus bidens Meyrick comb. nov. 58 - Labial palpus; 59 - Forewing venation; 60 - Hindwing venation; 61 - Male genitalia(ventral view) 
deeply notched in bidens, whereas, it is laceolate in pygmaeus. Regarding wing venation, though it is somewhat similar as far as the number and position of the radial veins is concerned yet it differs in respect of cubital veins, which are totally wanting in bidens and one cubital i.e., $\mathrm{CuA}_{1}$ is present in pygmaeus. After doing an evaluation of the aforesaid taxonomic characters for an appropriate placement of the species T. bidens Meyrick, to end its uncertain status, it is quite realistic and convincing that it cannot even form a new combination with any known genus of the family Pterophoridae (Meyrick, 1886; Fletcher, 1909, 1929, 1931; Yano, 1960, 1961a, 1961b, 1961c, 1963, 1964, 1965; Gielis, 1993, 2000). Accordingly, a new genus Prichotilus is proposed with Trichoptilus bidens Meyrick as its type-species and the same is fully diagnosed. Regarding the distribution of the species, it was earlier recorded from Khasi Hills in India by Meyrick (1930). The present collection from Renuka in Himachal Pradesh enriches the distributional record of this species.

\section{Stenodacma Amsel}

Stenodacma Amsel, 1959: Stutt. Beitr. Naturk., 28: 29

Type-species: Stenodacma iranells Amsel, 1959: ibidem., 28: 29 , by original designation.

\section{Dicussion}

A sample comprising 15 specimens belonging to three localities (Nauni (nine), PUP (five) and Dehradun (one)) was identified as Trichoptilus wahlbergi (Zeller) after comparison with the reference collections lying at FRI, Dehradun. After dissecting two males each from previous localities and single male from the last locality, it was inferred that the male genitalia of species belonging to the locality PUP differs from that of the genitalia of specimens belonging to other two localities. After critical examination of the figure of the male genitalia of Crombrugghia wahlbergi given by Gielis (1993), it was inferred that the specimens belonging to PUP are true $C$. wahlbergi. Having failed to identify the second species, the figure of genitalia was sent to Mr. Gielis who after critical examination of the same has suggested that the second species is Stenodacma pyrrhodes, which is very much closely allied to $S$. wahlbergi and has long been considered as a synonym of $C$. wahlbergi and possibly often misidentified as $C$. wahlbergi. Both these species can be separated on the basis that the sacculus lobe in $C$. wahlbergi is broader as compared to cucullus lobe, whereas, it is reverse in the second case. Accordingly, both these species are being redescribed as Stenodacma pyrrhodes (Meyrick) and $S$. wahlbergi (Zeller)

\section{Stenodacma pyrrhodes Meyrick}

Trichoptilus pyrrhodes Meyrick, 1889, Proc. Linn. Soc. NSW, 1889: 1113.

Material examined: 8 males, 1 female, 10-14.ix.1999, UHF, Nauni, Solan district, Himachal Pradesh, 1360m; 1 male, 25.iv.1999, FRI, Dehradun, Uttaranchal, 700m.

Distribution: Australia, India (Fletcher, 1931, Gielis, 1993).

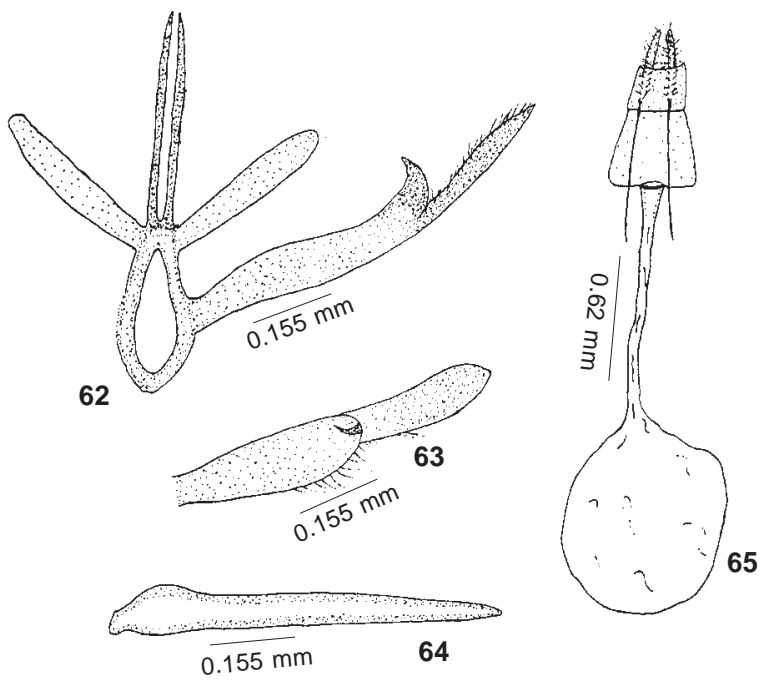

Figures 62-65. Stenodacma pyrrhodes Meyrick 62 - Male genitalia (ventral view); 63 - Right valva; 64 - Aedeagus; 65 - Female genitalia (ventral view)

\section{Diagnostic features}

Male genitalia (Figs. 62-64): Uncus bipartite, both lobes long, slender, pointed; tegumen bilobate, each lobe long, broad; valvae symmetrical, costa slightly arched, costa and sacculus separated as a lobe, ending in pointed hook, cucullus well separated, long and broad, distally pointed, inner surface furnished with fine hair.

Female genitalia (Fig. 65): Papillae anales long, slender, pointed, anterior apophyses missing, posterior apophyses moderately long, ostium bursae centrally placed, antrum slightly broader than remaining ductus bursae, ductus bursae long, slender, corpus bursae large, globular in shape, signum wanting.

Alar expanse: Male and female 11-12mm.

\section{Larval host plant: Unknown}

Remarks: The identification of the species has been confirmed after information received from Gielis (pers. comm.). The species has earlier been recorded from India as misidentification of $S$. wahlbergi Zeller. As mentioned in the remarks of the genus, the species is closely allied to the latter species.

\section{Stenodacma wahlbergi Zeller}

Pterophorus wahlbergi Zeller, 1852, Linn. Ent, 6: 346.

Material examined: 1 male, 24.vi.1998, 1 male, 4.x.1999, 1 male, 24.iv.2000, 1 female, 25.iv.2000, PUP, Patiala, Punjab, 250m; 1 male, Dunera, Gurdaspur district, Punjab, 700m.

Distribition: India (Palni Hills, Coimbatore, Sheveroys, Coorg, Bangalore, Pusa, Shillong, Bhim Tal, Dharmshala), Pakistan, Sri Lanka 

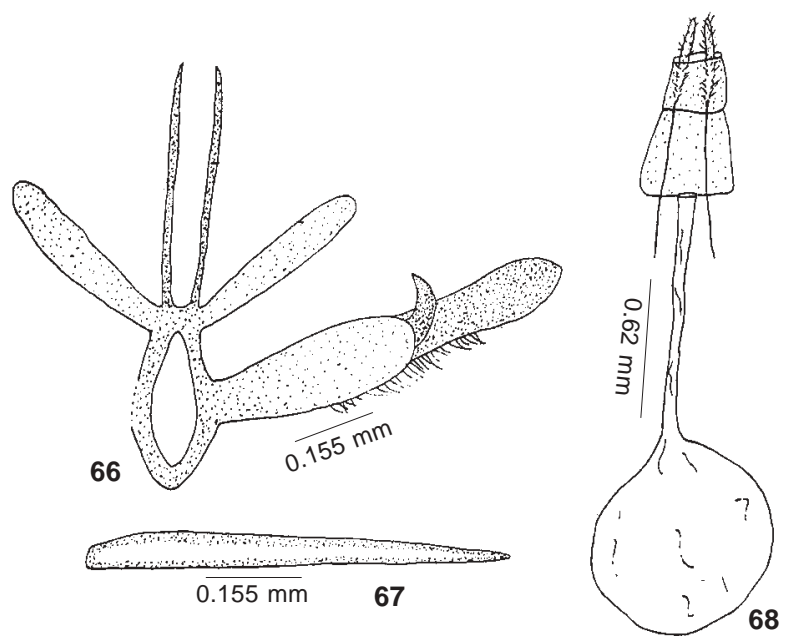

Figures 66-68. Stenodacma wahlbergi Zeller. 66 - Male genitalia (ventral view); 67 - Aedeagus; 68 - Female genitalia (ventral view)

\section{Diagnostic features}

Male genitalia (Figs. 66-67): Uncus bipartite, long, with each lobe slender, pointed, separate apart; tegumen bilobate, lobes long and broad; valvae symmetrical, costa slightly arched, costa and sacculus separated as a lobe, ending in pointed hook, hook well developed, prominent, cucullus well separated, long and broad, distally pointed, inner surface studded with fine hair and setae, terminal margin of sacculus and base of cucullus with a row of dense pair ventrally; aedeagus long, narrow, base slightly globular, gradually pointing apically, tip pointed.

Female genitalia (Fig. 68): Papillae anales long, slender, pointed, anterior apophyses absent, posterior apophyses moderately long, ostium bursae centrally placed, antrum slightly broader than remaining ductus bursae, ductus bursae long, slender, corpus bursae large, without signum.

Alar expanse: Male and female 10-11 mm.

Larval host plants: Oxalis, Ipomoea batatas, Vitis indica (Fletcher, 1931).

Remarks: The species has been identified after the comparison of its genitalia with the figure given by Gielis (1993). The species appears to be widely distributed and is known to occur throughout India.

\section{Conclusions}

The Pterophorid moths occupy a unique position in the order Lepidoptera in having clefted wings and number of clefts may vary from one to three in the forewing but always two in the hindwing. Two more families i.e., Alucitidae (Orneodidae) and Oxychirotidae also contain moths with clefted wings. In the former family, there are six lobes in each wing and there is a single cleft in either of the wings in the later family. The wings of various species of the pterophorid moths are narrow and appear like a ' $\mathrm{T}$ ' in the natural sitting posture. In view of their being smaller in size and with this type of sitting posture, it has been rather too difficult to detect the individuals attracted towards light or otherwise sitting on a substratum. According to Gielis (1993), the superfamily Pterophoroidea contains two families i.e., Pterophoridae and Macropiratidae. However, the later family having lone genus Agdistopis Hampson has been referred as a subfamily (Macropiratinae) of the family Pterophoridae by Minet (1991). In the present studies, 17 species i.e., Oxyptilus causodes Meyrick, Sphenarches anisodactylus Walker, Stenoptilia petraea Meyrick, Stenoptilodes taprobanes Felder and Rogenhöfer, Lantanophaga anellatus sp. nov., Amblyptilia forcipeta Zeller, Gypsochares catharotes Meyrick, Exelastis phlyctaenias Meyrick, E. pumilio Zeller, Tomotilus saitoi Yano, Procapperia pelecyntes Meyrick, Megalorrhipida paradefectalis sp. nov. M. defectalis Walker, M. gielisi sp. nov. Prichotilus bidens Meyrick, Stenodacma pyrrhodes Meyrick and S. wahlbergi Zeller of the subfamily Pterophorinae and species Deuterocopus planeta Meyrick of the Deuterocopinae have been dealtwith from northwestern India. The examination of the male genitalia of all these species reveals that genitalic characteristics are too diverse to infer anything at the family/ subfamily level. Mehta (1933) on the basis of examination of a lone species, Pterophorus pterodactyla Hübner, has mentioned that the Pterophoridae has simple type of male genitalia. As per present investigation, the male genitalia of the family Pterophoridae may vary from simple to complex and symmetrical to asymmetrical. The genera such as Procapperia Adamczewski, Sphenarches Meyrick, Tomotilus Yano, Prichotilus gen. nov. and Megalorrihipida Amsel possess simple and symmetrical type of male genitalia. In the genera Oxyptilus Zeller and Stenodacma Amsel, male genitalia are slightly modified with bilobed tegumen and valva divided into separate lobes representing sacculus and cucullus divisions. It has further been noticed that the cucullus gets modified into a beak-like structure giving it a specialized 'bird head-like' appearance in the genera Lantanophaga Zimmerman, Amblyptilia Hübner, Stenoptilia Hübner and Stenoptilodes Zimmerman. One of the species i.e., E. phlyctaenias Meyrick of the genus Exelastis Meyrick possess asymmetrical genitalia with saccular portion modified into spines, whereas, in the other species viz., E. pumilio Zeller, the genitalia is symmetrical in all respects. Also, in the genus Gypsochares Meyrick, the genitalia is asymmetrical one. The examination of the female genitalia of 10 species, viz., Sphenarches anisodactylus Walker, Stenoptilia petraea Meyrick, Lantanopahga anellatus sp. nov., Amblyptilia forcipeta Zeller, Exelastis phlyctaenias Meyrick, E. pumilio Zeller, Megalorrhipida defectalis Walker, M. gielisi sp. nov., Stenodacma pyrrhodes Meyrick and S. wahlbergi Zeller reveals that the anterior apophyses are usually reduced or wanting in all these taxa. Subject to the examination of the genitalia of more species referable to various Indian genera from other parts of the country, it is being emphasized that the segregation of different biological species of these moths is much easier on the basis of genitalic characters. In majority of the species, each individual has to be dissected to sort out the aspect of conspecificity of various taxa of species rank. 


\section{Key to the subfamilies of the family Pterophoridae}

1. Forewing clefted twice or thrice

Deuterocopinae

1A. Forewing always clefted only once

\section{Key to the genera of the subfamily Pterophorinae}

1A. Forewing always with less than five radial veins (one or more radial veins may be absent)

2A. Forewing with veins $R_{3}$ and $R_{4}$ stalked, $R_{2}$ free or stalked with $R_{1}$, male genitalia with tegumen simple, valva not as above, simple or bird head-like.....

3. Forewing with veins $R_{1}$ and $R_{2}$ stalked, hindwing with only one vein in each lobe, male genitalia with valva spoon-shaped

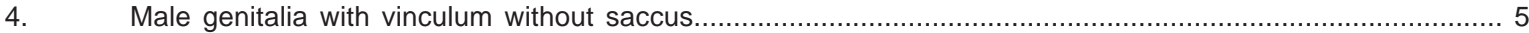

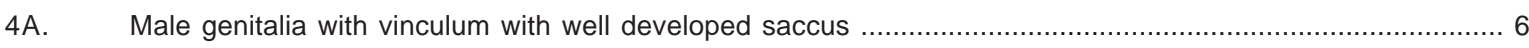

5. Male genitalia with uncus small, conical in shape ................................................. Stenoptilia Hübner

5A. Male genitalia with uncus long, slender, half to one times as long as tegumen ........... Stenoptilodes Zimmeman

6. Valva with sacculus smaller as compared to cucullus, the latter bilobate, upper lobe modified into a beak-like structure, vinculum produced anteriorly into a long and slender saccus, the latter forked at tip; female genitalia with antrum and ostium centrally placed, corpus bursae with signae S-shaped ........ Lantanophaga Zimmerman

6A. Valva with sacculus comparatively much longer than cucullus, the latter not bilobate, reduced, tip modified into a beak-like structure, saccus flat, the latter plate-like, bordered by a brush of hair forming comb-shaped appearance; female genitalia with antrum and ostium laterally placed, corpus bursae with signae horn-shaped Amblyptilia Hübner

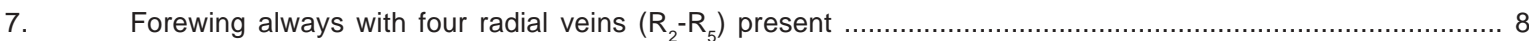

7A. Forewing always with less than four radial veins ....................................................................... 11

8. Forewing with all four radials free, male genitalia strongly asymmetrical, asymmetry prominent in cucullus region of valva, the former modified into spines

Gypsochares Meyrick

8A. Forewing with vein $R_{3}$ and $R_{4}$ stalked, male genitalia usually symmetrical, asymmetry (if any) prominent in

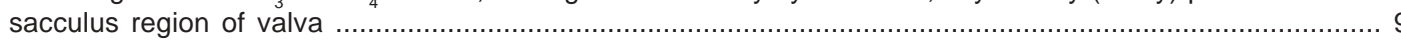

9. Male genitalia asymmetrical or symmetrical, saccus well developed Exelastis Meyrick

9A. Male genitalia symmetrical, saccus reduced or absent 10

10. Male genitalia with uncus present, well developed, fleshy, densely hairy, more than half as long as tegumen, valva trapezoidal ventrally, with a sharp thorn-like process near apex Tomotilus Yano

10A. Male genitalia with uncus absent, tegumen pointedly raised in the middle, cucullus long and broad, separable by a long neck, dorsal margin straight, ventral margin convex, aedeagus strongly sinuate, more or less S-shaped Procapperia Adamczewski

11. Vertex beset with modified erect scales, forewing with veins $R_{2}, R_{3}$ and $R_{4}$ present, $R_{1}$ and $R_{5}$ absent; male genitalia with uncus extremely wide and fleshy, densely hairy, valva simple, more or less oval in outline, female genitalia with two small bean-like signae present in the corpus bursae Megalorrhipida Amsel

11A. Vertex without modified scales, forewing with veins $R_{2}$ and $R_{4}$ present; male genitalia with uncus conical and fleshy, valva complex in structure, female genitalia usually without signum

12. Male genitalia with uncus simple, conical and fleshy, tegumen simple, valva with cucullus deeply notched terminally, dorsally produced into a finger-like projection, aedeagus relatively reduced .... Prichotilis gen. nov.

12A. Male genitalia with uncus bipartite, long, both lobes slender, tegumen bilobate, lobes wide apart, laterally directed, valva with cucullus lobe separated from saccular lobe, aedeagus longer Stanodacma Amsel 


\section{Key to the species of the genus Exelastis Meyrick}

1. Male genitalia with uncus broad, fleshy, valvae asymmetrical, sacculus ending into saccular spines; female genitalia with antrum broad and well developed . phlyctaenias Meyrick

1A. Male genitalia with uncus narrow, valvae symmetrical, sacculus ending into a rounded lobe; female genitalia with antrum reduced pumilio Zeller

Key to the species of the genus Megalorrhipida Amsel

1. Male genitalia with uncus four times longer than breadth at base, length of valva more than double its breadth in the middle, aedeagus produced into needle-like projection posteriorly paradefectalis sp. nov.

1A. Male genitalia with uncus only twice or slightly more than twice breadth of its base, length of valva less than twice its breadth in the middle, aedeagus not as above

2. Male genitalia with uncus strongly concave dorsally, aedeagus tip rounded; female genitalia with antrum small, simple defectalis Walker

2A. Male genitalia with uncus slightly concave dorsally, aedeagus with lower lip pointed, female genitalia with antrum funnel-shaped gielesi sp. nov.

\section{Key to the species of the genus Stenodacma Amsel}

1. Male genitalia with sacculus broad as compared to cucullus pyrrhodes Meyrick

1A. Male genitalia with sacculus narrow as compared to cucullus wahlbergi Zeller

\section{REFERENCES}

Adamczewski, S. (1951). On the systematics and origin of the generic group Oxyptilu Zeller (Lepidoptera: Alucitidae). Bulletin British Museum Natural History (Entomology) I(5): 301-388, pls. 9-20.

Arenberger, E. (1988). Pterophoridae aus Kaschmir. Zeit Arbeit Ostet Entomology 40(1/2): 23-32.

Common, I.F.B. (1970). Lepidoptera (moths and butterflies). In: The Insect of Australia, Melbourne University Press, Melbourne: 866pp.

Fletcher, T.B. (1909). The plume-moths of Ceylon. Spolea Zeylonica VI(XXI): 1-39.

Fletcher, T.B. (1914). Some South Indian Insects. Madras, 565pp.

Fletcher, T.B. (1921). Life histories of Indian Insects (Microlepidoptera). Memoir Department Agriculture India (Entomology) Calcutta 6: 1-217.

Fletcher, T.B. (1925). On Walker's types of Plume moths in the National Collection,redescriptions and notes (Lepidoptera). Transactions Entomological Society London 599-639.

Fletcher, T.B. (1926). On Walker's types of Plume-moths in the National Collection;Redescriptions and Notes. Transactions Entomological Society London 599-639.

Fletcher, T.B. (1929). A list of generic names used for Microlepidoptera. Memoir Department Agriculture India (Entomology) Calcutta 11: ix+244pp.

Fletcher, T.B. (1931). Catalogue of Indian Insects, Part 20 - Alucitidae (Pterophoridae). Govt. of India Central Publication branch, Calcutta, 61pp.

Fletcher, T.B. (1940). A new Indian plume-moth (Alucitidae: Lepidoptera). Indian Journal of Entomology II(I): 11-12.

Gielis, C. (2000). Stenoptilia caoenei sp. nov. from Kyrgyzstan (Lepidoptera: Pterophoridae). Phagea 28(4): 127.

Mathews, D.L., (1989). The Plume moths of Florida, xv+347pp.

Mehta, D.R. (1933). Comparative morphology of the male genitalia in Lepidoptera. Records of the Indian Museum XXXV: 197-266.

Meyrick, E. (1886). On the classification of the Pterophoridae. Transactions Entomological Society of London 1886: 1-21.

Meyrick, E. (1905). Descriptions of Indian Microlepidoptera. Journal of the Bombay Natural History Society 16: 580-619.

Meyrick, E. (1906). Descriptions of Indian Microlepidoptera. Journal of the Bombay Natural History Society 17: 133-153, 403-417.

Meyrick, E. (1907). Descriptions of Indian Microlepidoptera. Journal of the Bombay Natural History Society 17: 730-794;

Meyrick, E. (1911). Descriptions of Indian Microlepidoptera. Journal of the Bombay Natural History Society 21: 104-131, 852-877;

Meyrick, E. (1930). Exotic Microlepidoptera. III: 532-640.

Minet, J. (1991). Tentative reconstruction of the ditrysian phylogeny
(Lepidoptera: Glossata). Entomologica Scandinavica 22: 69-95.

Robinson, G.S. (1976). The preparation of slides of Lepidoptera genitalia with special reference to Microlepidoptera. Entomology Gazette 27(2): 127-132.

Robinson, G.S., K.T. Tuck and M. Schaefer (1994). A Field Guide to the Smaller Moths of South-East Asia. Malaysian Nature Society, 482 pp.

Roonwall, M.L., R.N. Mathur, G.D. Bhasin, P.N. Chatterjee, P.K. SenSharma, B. Singh, A. Chandra, R.S. Thapa and K. Krishna (1964). A systematic catalogue of the main identified entomologica collection at the Forest Research Institute, Dehradun, Parts 22-38, 197-537pp.

Walsingham, M.A. (1880). Pterophoridae of California and Oregon: i-xvi, 166,3 plates.

Yano, K. (1960). New or little known species of the genus Platyptilia Hübner from Japan (Lepidoptera: Pterophoridae). Mushi 34(6): 137-141.

Yano, K. (1961a). A new genus of Pterophoridae from Japan (Lepidoptera). Mushi 35(12):87-90.

Yano, K. (1961b). Descriptions of two new species of Pterophoridae from Japan (Lepidoptera). Kontyû 29(3): 151-156.

Yano, K. (1961c). On the species of the genus Nippoptilia Matsumura from Japan, with description of anew species (Lepidoptera: Pterophoridae). Entomology Laboratory University Osaka 6: 71-78+1 pl.

Yano, K. (1963). Notes on South Pacific Pterophoridae (Lepidoptera). Pacific Insects 5(4):849-871.

Yano, K. (1964). Notes on Pterophoridae from the Ryukyus (Lepidoptera). Kontyû 32(3): 437-442.

Yano, K. (1965). Some Plume-moths from Formosa (Lepidoptera: Pterophoridae). Special Bulletin of Lepidoptera Society Japan 1: 36-39.

Zimmerman, E.C. (1978). Microlepidoptera. Insects of Hawaii, Vol 9. University Press of Hawai, Honolulu, xviii+1903pp.

\section{ACKNOWLEDGEMENTS}

Professor H.S. Rose is grateful to the Ministry of Environment and Forests (Govt. of India), New Delhi for funding the project on Microlepidoptera and to the Vice-Chancellor, Punjabi University, Patiala for providing all necessary facilities to set up the Coordinating Centre under an All India Coordinated Project on Taxonomy (AICOPTAX) programme of the Central Government. HSR is also thankful to Mr. Onkarpreet Singh Jutla for setting the text of the electronic version. Authors are also highly obliged to Mr. Cees Gielis (the Netherlands) for sending literature and appreciate him for quick response to various queries. Thanks are also due to Mr. Kevin Tuck of the NHM, London for sending the photograph of the male genitalia of certain species. 